\title{
SUPLEMENT 2
}

\author{
Zastosowanie wemurafenibu \\ u chorych na uogólnionego czerniaka \\ z obecnością mutacji w genie $B R A F$ \\ - wybrane przypadki kliniczne
}

Dorota Kwapisz, Katarzyna Kozak, Elżbieta Turska,

Ewa Kalinka-Warzocha, Tomasz Świtaj, Sławomir Falkowski,

Piotr Rutkowski 



\title{
Zastosowanie wemurafenibu u chorych na uogólnionego czerniaka z obecnością mutacji w genie BRAF — wybrane przypadki kliniczne
}

\author{
Dorota Kwapisz' ${ }^{1}, K$ atarzyna Kozak ${ }^{1}$ Elżbieta Turska², \\ Ewa Kalinka-Warzocha², Tomasz Świtaj ${ }^{1}$, \\ Sławomir Falkowski ${ }^{1}$, Piotr Rutkowski ${ }^{1}$
}

Liczba zachorowań na czerniaka skóry stale wzrasta. Podstawowym leczeniem we wczesnym stadium zaawansowania choroby pozostaje zabieg chirurgiczny. Nowe terapie, takie jak immunoterapia czy selektywne inhibitory BRAF - wemurafenib czy dabrafenib, poprawiły wyniki leczenia w grupie chorych w IV stopniu zaawansowania. W Polsce w praktyce klinicznej w ramach programu lekowego dostępny jest wemurafenib. W pracy prezentujemy doświadczenia z wykorzystaniem wemurafenibu w leczeniu chorych na uogólnionego czerniaka z potwierdzoną obecnością mutacji BRAF.

The use of vemurafenib in BRAF-positive metastatic melanoma patients - selected cases reports The incidence of cutaneous melanoma is constantly increasing. The primary treatment in early stage of disease remains surgery. New therapeutic strategies such as immunotherapy or selective BRAF inhibitors — vemurafenib and dabrafenib, have improved outcomes of treatment in the group of patients with stage IV melanoma. In Poland still only vemurafenib is available in routine clinical practice. In this article we present clinical experiences in treating of $B R A F$-positive metastatic melanoma patients with use of vemurafenib.

Słowa kluczowe: czerniak, wemurafenib, opis przypadku

Key words: melanoma, vemurafenib, case report

\section{Wstęp}

Czerniaki skóry są w Polsce nowotworami o największej dynamice wzrostu liczby zachorowań. Mediana wieku zachorowania jest podobna dla obu płci i wynosi około 50 lat [1]. Czerniak stanowi ok. 2\% wszystkich zachorowań na nowotwory i odpowiada za $80 \%$ zgonów z powodu złośliwych nowotworów skóry [2]. Jest nowotworem wyleczalnym tylko we wczesnych stadiach rozwoju, a warunkiem wyleczenia jest wykrycie we wczesnym stadium i szybkie radykalne leczenie operacyjne [1]. W chwili rozpoznania czerniaka skóry zaledwie u 15\% i 5\% chorych stwierdza się odpowiednio chorobę w stadium regionalnego zaawansowania i jej uogólnienia [3]. Jednak leczenie tych grup chorych stanowi nadal wyzwanie dla onkologów w ich codziennej praktyce klinicznej. Wskaźniki 5-letnich przeżyć chorych w stadium regionalnego zaawansowania i uogólnienia choroby odpowiednio wynoszą 20-70\% i 5-10\% [1].

Chorzy na czerniaka w IV stopniu zaawansowania choroby mają najgorsze rokowanie, a mediana czasu przeżycia całkowitego wynosi 6-10 miesięcy. Najważniejszymi

\footnotetext{
${ }^{1}$ Klinika Nowotworów Tkanek Miękkich, Kości i Czerniaków 
czynnikami rokowniczymi u chorych w tym stadium są — stan sprawności oraz lokalizacja ognisk przerzutowych [1].

Możliwości leczenia chirurgicznego u chorych na uogólnionego czerniaka są ograniczone, a zarejestrowanym lekiem cytotoksycznym w tym wskazaniu jest dakarbazyna, przy czym jej skuteczność jest ograniczona [1].

Postęp w leczeniu tej grupy chorych jest związany przede wszystkim z rozwojem immunoterapii wykorzystującej przeciwciała anty-CTLA-4 (anti-cytotoxic Tlymphocyte antygen-4) i anty-PD-1 (anti-Programmed Death-1) oraz leczenia ukierunkowanego molekularnie. Ipilimumab jest ludzkim przeciwciałem monoklonalnym anty-CTLA-4 $(\operatorname{lgG} 1 \kappa)$, zarejestrowanym do leczenia chorych na nieresekcyjnego lub przerzutowego czerniaka po niepowodzeniu wcześniejszej terapii $[3,4]$. Przy wykorzystaniu ipilimumabu obserwuje się odpowiedź dopiero po około 3-4 miesiącach, co ogranicza jego zastosowanie u chorych z minimalnymi objawami, w dobrym stanie sprawności, o powolnym przebiegu choroby oraz bez towarzyszących chorób autoimmunologicznych [3]. Ipilimumab jest podstawową opcją leczenia chorych bez mutacji w genie BRAF [1, 3]. Obecnie trwają badania oceniające skuteczność i bezpieczeństwo zastosowania przeciwciał anty-PD-1 (niwolumab, lambrolizumab) u chorych na nieresekcyjnego lub uogólnionego czerniaka [5-7].

Mutacje somatyczne w genie BRAF obserwuje się w 50-70\% czerniaków skóry powstających w miejscach nienarażonych na długotrwałe działanie promieni słonecznych (NCSD - non-chronic sun-damage) [1, 8]. Około 74-90\% wszystkich mutacji w genie BRAF dotyczy mutacji punktowej typu zmiany sensu spowodowanej substytucją waliny (V) przez kwas glutaminowy (E) w pozycji 600 egzonu 15 (p.V600E), a około 5-29\% dotyczy mutacji V600K, gdzie dochodzi do substytucji waliny (V) przez lizynę (K) [9-13]. Mutacja prowadzi do wielokrotnego zwiększenia aktywności kinazy BRAF, czego konsekwencją jest stymulacja sygnałów ERK, proliferacja komórek i przyrost masy guza [11, 14]. Informacje te stały się podstawą do poszukiwań leku hamującego kinazę serynowo-treoninową BRAF. Wemurafenib jest doustnym drobnocząsteczkowym inhibitorem wspomnianej kinazy, który został zarejestrowany do leczenia w monoterapii dorosłych chorych na nieresekcyjnego lub uogólnionego czerniaka wykazującego mutację BRAFV600 w oparciu o wyniki badania BRIM-3, gdzie wykazano przy stosowaniu wemurafenibu wydłużenie czasu przeżycia wolnego od progresji czerniaka (PFS - progression-free survival) i czasu przeżycia całkowitego (OS - overall survival) względem leczenia dakarbazyną [15-17]. Inhibitory BRAF powodują szybką odpowiedź oraz kontrolę nowotworu u większości chorych, przy ograniczonym czasie trwania odpowiedzi związanym z aktywacją mechanizmów oporności. Mediana czasu trwania odpowiedzi wynosi około 6-7 miesięcy [1]. Nie ma jeszcze ustalonego optymalnego czasu rozpoczęcia terapii oraz kolejności zastosowania inhibitora BRAF w sekwencji leczenia chorych na uogólnionego czerniaka. Dotychczasowe dane sugerują zachowanie aktywności inhibitorów BRAF również po leczeniu ipilimumabem [1, 18]. Wydaje się, że są to leki z wyboru u chorych na nieresekcyjnego lub uogólnionego czerniaka z wykazaną mutacją w genie $B R A F$, którym towarzyszą objawy choroby i stwierdza się dużą masę nowotworu, przed rozpoczęciem immunoterapii [1, 18]. Należy zwrócić uwagę na możliwość wywołania progresji nowotworów związanych z mutacją RAS po zastosowaniu wemurafenibu [19]. Najczęstszymi działaniami niepożądanymi wemurafenibu są zmiany skórne pod postacią wysypki i nadwrażliwości na światło, nowotwory skóry (rak kolczystokomórkowy cuSCC - cutaneous squamous cell carcinoma, keratoacanthoma) oraz bóle stawów i zmęczenie [15].

W maju 2013 roku został zarejestrowany przez amerykańską Agencję ds. Żywności i Leków (FDA — Food and Drug Administration) kolejny inhibitor BRAF — dabrafenib oraz inhibitor MEK - trametynib. Rejestracja obu leków obejmuje ich zastosowanie u chorych na nieresekcyjnego lub uogólnionego czerniaka z wykazaną mutacją V600 [20].

W Polsce wśród leków ukierunkowanych molekularnie dostępny jest od czerwca 2013 roku wemurafenib w ramach programu lekowego [21]. Pozostałe wcześniej wspomniane leki można zastosować jedynie w ramach badań klinicznych. Z uwagi na krótki czas, który upłynął od uzyskania szerszej dostępności w Polsce do leczenia wemurafenibem i jednocześnie mając na względzie wcześniejsze doświadczenie naszego ośrodka w zastosowaniu tego leku, autorzy tej publikacji uznali za zasadne podzielenie się zdobytą wiedzą w tym zakresie. Poniżej zostaną przytoczone opisy procesów leczniczych wybranych chorych na uogólnionego czerniaka z potwierdzoną mutacją w genie BRAF leczonych wemurafenibem w Klinice Nowotworów Tkanek Miękkich, Kości i Czerniaków w Centrum Onkologii - Instytucie w Warszawie oraz przypadek chorego leczonego w Pododdziale Diagnostyki i Terapii Onkologicznej Oddziału Chemioterapii w Łodzi, u którego obserwowano zaburzenia czynności wątroby w trakcie terapii selektywnym inhibitorem BRAF, a modyfikacja dawki pozwoliła na kontynuowanie leczenia.

Do oceny stopnia toksyczności leczenia zastosowano kryteria według CTCAE wersji 4.0 (Common Terminology Criteria for Adverse Events, version 4.0), a oceny odpowiedzi na leczenie dokonywano za pomocą kryteriów RECIST wersji 1.1 (Response Evaluation Criteria In Solid Tumors, version 1.1). Do identyfikacji mutacji w kodonie V600 BRAF zastosowano zwalidowany test Cobas 4800 BRAF V600 Mutation Test.

\section{Opis przypadku 1}

We wrześniu 2011 roku do Kliniki Nowotworów Tkanek Miękkich, Kości i Czerniaków został przyjęty 56-letni mężczyzna z rozpoznanym czerniakiem guzkowym skóry ramienia prawego, w stopniu zaawansowania miejscowego ocenionym na pT4a. U chorego wykonano radykalne wy- 
cięcie blizny po biopsji wycinającej oraz biopsję węzła wartowniczego prawego dołu pachowego, zgodnie z uwidocznioną w badaniu scyntygraficznym drogą spływu chłonki. W 5 usuniętych węzłach chłonnych nie znaleziono wówczas utkania komórek czerniaka, a w badaniach obrazowych nie uwidoczniono cech uogólnienia choroby. Stopień zaawansowania choroby oceniono na IIB zgodnie z klasyfikacją według Amerykańskiej Połączonej Komisji do spraw Raka (AJCC, American Joint Committee on Cancer) z 2010 roku.

Rok później u chorego w badaniu przedmiotowym stwierdzono na ramieniu prawym $1,5 \mathrm{~cm}$ guzek w tkance podskórnej, a w dole pachowym prawym — dwa $1 \mathrm{~cm}$ guzki w skórze i powiększony 1,5 cm węzeł chłonny. Wynik biopsji aspiracyjnej cienkoigłowej (BAC) potwierdził przerzut czerniaka do węzła chłonnego. W związku z powyższym wykonano u chorego limfadenektomię, usuwając 10 węzłów chłonnych dołu pachowego prawego oraz zmiany w obrębie tkanki podskórnej ramienia. Potwierdzono wznowę miejscową oraz przerzuty in-transit w usuniętych guzkach tkanki podskórnej ramienia i skóry dołu pachowego prawego. Z powodu nieradykalnego mikroskopowo usunięcia wznowy w bliźnie po zmianie pierwotnej chory otrzymał radioterapię na tę okolicę $z$ wykorzystaniem elektronów do dawki całkowitej 2400 cGy.

W marcu 2013 roku, dwa miesiące po zakończonej radioterapii, uwidoczniono w konwencjonalnym badaniu radiologicznym klatki piersiowej zmiany ogniskowe mogące odpowiadać przerzutom. U chorego wykonano badania tomografii komputerowej (TK) jamy brzusznej, miednicy i klatki piersiowej stwierdzając 9 przerzutów ograniczonych do płuc o maksymalnym wymiarze $11 \mathrm{~mm}$.

Czternaście lat wcześniej rozpoznano u chorego utrwalone migotanie przedsionków. W badaniu elektrokardiograficznym (EKG) stwierdzono migotanie przedsionków z czynnością komór 100/min, ze wstawkami częstoskurczu nadkomorowego 150/min, bez cech niedokrwienia a skorygowany czas trwania odstępu QTc (QT corrected) oceniono na mniej niż 500 milisekund (ms). Chory pozostawał pod stałą opieką kardiologa, stosując się do jego zaleceń. Po zidentyfikowaniu mutacji w kodonie V600 BRAF w materiale z usuniętego czerniaka i wykonaniu niezbędnych badań chory rozpoczął leczenie wemurafenibem w dawce należnej 960 mg dwa razy na dobę w ramach programu lekowego. Po dwóch miesiącach leczenia wemurafenibem stwierdzono częściową regresję zmian miąższowych w płucach, uwidaczniają c w badaniu tomografii komputerowej klatki piersiowej 5 zmian przerzutowych w tym największą o wymiarze $4 \mathrm{~mm}$. Chory dobrze tolerował leczenie. Od drugiego miesiąca terapii utrzymuje się u chorego wysypka drobnogrudkowa 1. stopnia, a w piątym miesiącu wystąpiła biegunka 2. stopnia. Ponadto przejściowo obserwowano wzrost aktywności fosfatazy zasadowej (ALP - alkaline phosphatase), gamma-glutamylotranspeptydazy (GGTP — gamma-glutamyl transpeptidase) oraz stężenia glukozy i bilirubiny całkowitej w surowicy niewymagające redukcji dawki leku. Chory kontynuuje szósty miesiąc leczenia inhibitorem BRAF.

\section{Omówienie przypadku 1}

U chorego proces leczniczy został przeprowadzony zgodnie z obowiązującymi zaleceniami [1]. Po stwierdzeniu klinicznie powiększonego węzła chłonnego dołu pachowego prawego oraz zmian przerzutowych in-transit i potwierdzeniu w materiale uzyskanym za pomocą BAC obecności komórek czerniaka, wykonano resekcję ograniczonych lokoregionalnie ognisk czerniaka. Z uwagi na kilkakrotne zabiegi operacyjne w obrębie blizny po usunięciu zmiany pierwotnej i nieradykalne wycięcie wznowy zdecydowano się zastosować u chorego uzupełniające napromienianie na tę okolicę. Nie stwierdzono wówczas cech uogólnienia choroby. Chory został poddany obserwacji i w wykonanych badaniach obrazowych, po dwóch miesiącach od ostatniej wizyty, stwierdzono przerzuty do płuc. Ze względu na wykazanie obecności mutacji w genie BRAF i spełnieniu kryteriów programu lekowego rozpoczęto terapię wemurafenibem [21]. Chory odniósł korzyść z leczenia w postaci częściowej regresji zmian przerzutowych w płucach przy niewielkiej toksyczności terapii. Warto zauważyć, że pomimo obciążenia współwystępowaniem utrwalonego migotania przedsionków chory dobrze tolerował leczenie, a w kontrolnych badaniach elektrokardiograficznych nie znaleziono przesłanek zmuszających do redukcji czy wręcz zaprzestania podawania wemurafenibu.

Rozwinięta u chorego toksyczność skórna oraz zwiększona aktywność enzymów wątrobowych stopnia 1. nie wymuszała modyfikacji dawki leku (tab. I). W badaniu III fazy bardzo często odnotowywano wzrost aktywności GGTP, często aminotransferazy alaninowej (AIAT, ALT, alanine aminotransferase), ALP i bilirubiny oraz niezbyt często aminotransferazy asparaginianowej (AspAT, AST aspartate aminotransferase) $[15,16]$.

Odpowiedź na leczenie utrzymuje się do dnia dzisiejszego bez nasilenia działań niepożądanych.

\section{Opis przypadku 2}

Mężczyzna 44-letni zgłosił się do szpitala rejonowego w kwietniu 2013 roku z powodu dolegliwości bólowych w nadbrzuszu, wymiotów oraz luźnych stolców. Chory początkowo był hospitalizowany w oddziale obserwacyjno-zakaźnym, w którym przeprowadzono wstępną diagnostykę.W badaniach laboratoryjnych nie stwierdzono istotnych klinicznie odchyleń od normy. Uzyskano także ujemne wyniki testów przeprowadzonych w celu wykluczenia wirusowej lub bakteryjnej etiologii choroby.W wykonanym badaniu ultrasonograficznym jamy brzusznej nie stwierdzono nieprawidłowości, natomiast w badaniu tomografii komputerowej jamy brzusznej zobrazowano pogrubiałą ścianę żołądka do $21 \mathrm{~mm}$. W wykonanej 
Tabela I. Schemat modyfikacji dawki wemurafenibu z uwzględnieniem stopnia jakiegokolwiek z działań niepożądanych [14]

\begin{tabular}{|c|c|}
\hline $\begin{array}{l}\text { Stopień działania niepożądanego } \\
\text { (CTCAE v.4.0) }\end{array}$ & $\begin{array}{l}\text { Wemurafenib (W) } \\
\text { (dawka dobowa) }\end{array}$ \\
\hline Stopień 1 lub 2 - tolerowane & $960 \mathrm{mg} \times 2$ \\
\hline \multicolumn{2}{|l|}{ Stopień 2 - nietolerowany } \\
\hline \multicolumn{2}{|l|}{ Stopień 3} \\
\hline — pierwszy raz & $\begin{array}{l}\text { 1. Przerwać leczenie W do złagodzenia objawów do stopnia 0-1 } \\
\text { 2. Wznowić W } 720 \mathrm{mg} \times 2 \\
\text { (lub } 480 \mathrm{mg} \times 2-\text { jeśli dawka była już zmniejszana) }\end{array}$ \\
\hline $\begin{array}{l}\text { - drugi raz lub utrzymywanie się stopnia 2. lub 3. po } \\
\text { przerwaniu leczenia }\end{array}$ & $\begin{array}{l}\text { 1. Przerwać leczenie W do złagodzenia objawów do stopnia 0-1 } \\
\text { 2. Wznowić W } 480 \mathrm{mg} \times 2 \text { (lub zakończyć leczenie, jeśli redukowano już dawkę } \\
\text { do ww.) }\end{array}$ \\
\hline $\begin{array}{l}\text { - trzeci raz lub utrzymywanie się stopnia 2. lub } 3 . \\
\text { po drugim zmniejszeniu dawki }\end{array}$ & Zakończyć leczenie \\
\hline \multicolumn{2}{|l|}{ Stopień 4} \\
\hline — pierwszy raz & $\begin{array}{l}\text { 1. Zakończyć leczenie } \\
\text { lub } \\
\text { 1. Przerwać W do uzyskania złagodzenia objawów do stopnia 0-1 } \\
\text { 2. Wznowić W } 480 \mathrm{mg} \times 2 \text { (lub zakończyć leczenie, jeśli redukowano już dawkę } \\
\text { do ww.) }\end{array}$ \\
\hline $\begin{array}{l}\text { - drugi raz lub utrzymywanie się stopnia } 4 . \\
\text { po pierwszym zmniejszeniu dawki }\end{array}$ & Zakończyć leczenie \\
\hline
\end{tabular}

CTCAE v.4.0 (Common Terminology Criteria for Adverse Events version 4.0) - klasyfikacja stopni działań niepożądanych wersja 4.0, W — wemurafenib (vemurafenib)

gastroskopii stwierdzono mierne przekrwienie błony śluzowej żołądka oraz przepuklinę rozworu przełykowego. Z powodu nieustępujących dolegliwości bólowych w nadbrzuszu, ponowiono u chorego diagnostykę endoskopową oraz wykonano badanie przeglądowe jamy brzusznej. W kolejnej gastroskopii stwierdzono dodatkowo nadżerkę kompletną na tylnej ścianie trzonu żołądka oraz duże zaleganie treści brunatnej w żołądku. W dziewiątej dobie hospitalizacji chorego z cechami niedrożności przekazano do oddziału chirurgii ogólnej i urazowej. Tego samego dnia przeprowadzono u chorego laparotomię z odpreparowaniem wgłobienia jelita krętego, odcinkową resekcją jelita krętego i czczego oraz appendektomię. W otrzymanym wyniku badania histopatologicznego rozpoznano czerniaka jelita cienkiego.

Miesiąc po leczeniu operacyjnym chory był konsultowany w Centrum Onkologii — Instytucie w Warszawie, gdzie potwierdzono rozpoznanie histopatologiczne (melanoma malignum melanoticum — naciek ściany jelita cienkiego; HMB-45 +). U chorego utrzymywały się stałe dolegliwości bólowe brzucha. Z nieprawidłowości w badaniu przedmiotowym stwierdzono nieznaczne powiększenie węzłów chłonnych pachwinowych oraz tkliwość w nadbrzuszu. Nie stwierdzono zmian barwnikowych skóry podejrzanych o ognisko pierwotne czerniaka.

W celu oceny stopnia zaawansowania choroby w czerwcu 2013 roku wykonano u chorego TK głowy, klatki piersiowej, jamy brzusznej i miednicy. W płacie czołowym lewej półkuli mózgu stwierdzono $6 \mathrm{~mm}$ zmianę o niejednoznacznym charakterze oraz powiększone węzły chłonne w lewym śródbrzuszu do $20 \mathrm{~mm}$. U chorego zidentyfikowano mutację w kodonie V600 BRAF w badanym materiale $\mathrm{z}$ wyciętego ogniska czerniaka. W badaniach laboratoryjnych nie stwierdzono istotnych odchyleń od normy. Chory czasowo wymagał modyfikacji leczenia przeciwbólowego.

Po wykonaniu niezbędnych badań pacjent od lipca 2013 roku rozpoczął leczenie wemurafenibem w dawce 960 mg dwa razy dziennie. Po miesiącu przyjmowania leku oprócz zwiększenia aktywności dehydrogenazy mleczanowej (LDH - lactate dehydrogenase) do 233 IU/I (zakres normy 85-227 IU/I) nie wykazano innych istotnych klinicznie nieprawidłowości w badaniach laboratoryjnych. Odnotowano natomiast pojawienie się skórnych działań niepożądanych leku. U chorego na skórze głowy i tułowia obserwowano grudkową wysypkę 2. stopnia z towarzyszącym świądem. Ponadto rozpoznano erytrodyzestezję dłoniowo-podeszwową (PPE — palmar-plantar erythrodysesthesia) stopnia 2. oraz zmiany owrzodziałe na skórze uszu. Z powodu wspomnianych zmian skórnych oraz bardzo nasilonego świądu całej skóry w porozumieniu z lekarzem prowadzącym chory nie przyjmował leku przez 7 dni. Po ustąpieniu świądu wznowiono leczenie wemurafenibem w zredukowanej dawce 2 razy dziennie po 720 mg do łącznej dawki dobowej 1440 mg. Po miesiącu leczenia w mniejszej dawce utrzymywały się akceptowalne przez chorego: PPE oraz grudkowa wysypka na skórze głowy i tułowia 2. stopnia, lecz bez towarzyszącego świądu.

W badaniach obrazowych stwierdzono stabilizację choroby, a opisywana zmiana w ośrodkowym układzie nerwowym (OUN) pozostaje niema klinicznie. Po kolejnym miesiącu leczenia działania niepożądane nie nasiliły się. Chory kontynuuje piąty miesiąc terapii inhibitorem BRAF w dawce zredukowanej. 


\section{Omówienie przypadku 2}

Po pierwszej ocenie odpowiedzi na leczenie wemurafenibem u chorego na zaawansowanego czerniaka z obecnością mutacji BRAF bez znanego ogniska pierwotnego stwierdzono stabilizację choroby.

U chorego wystąpiła toksyczność skórna, która jest najczęstszym działaniem niepożądanym obserwowanym w trakcie leczenia wemurafenibem i jednocześnie głównym powodem redukcji dawki [22]. Zgodnie z zaleceniami z powodu nietolerowanej toksyczności skórnej 2. stopnia przerwano leczenie u naszego chorego do czasu uzyskania złagodzenia objawów, a następnie wznowiono podawanie inhibitora BRAF w dawce zredukowanej. W tabeli I przedstawiono schemat modyfikacji dawki leku w oparciu o stopień działań niepożądanych [15].

Spośród skórnych działań niepożądanych wemurafenibu wymienić można: wysypkę (najczęściej o charakterze grudkowo-plamistym i okołomieszkową), fototoksyczność, utratę lub zmianę struktury włosów, wystąpienie raka kolczystokomórkowego skóry (cuSCC - cutaneous squamous cell carcinoma), w tym przypadki sklasyfikowane jako rogowiak kolczystokomórkowy (KA - keratoacanthoma), podtyp mieszany z keratoakantomą oraz nowe pierwotne ognisko czerniaka [15]. Ponadto zaobserwować można zmiany hiperkeratotyczne, PPE, określanej mianem zespołu ręka-stopa, którą prezentował omawiany chory oraz zapalenie tkanki tłuszczowej (panniculitis).

Ostatnio zwrócono uwagę na nowe raportowane rzadkie powikłanie terapii, jakim jest wysypka polekowa z eozynofilią i objawami układowymi (zespół DRESS — drug rash with eosinophilia and systemic symptoms). W przypadku rozwinięcia się u chorego zespołu DRESS należy definitywnie zaprzestać terapii wemurafenibem [19].

Lacouture ME i wsp. wykazali, że u 92-95\% z pośród 520 chorych leczonych wemurafenibem doszło do wystąpienia toksyczności skórnej. Najczęściej odnotowano wysypkę (64-75\%), nadwrażliwość na światło (35-63\%), w dalszej kolejności PPE (8-10\%) oraz w 19-26\% cuSCC, w tym z przewagą KA. Większość chorych kontynuowała terapię, a modyfikacji leczenia wymagało mniej niż 10\% chorych. Wystąpienie powikłania skórnego nie korelowało z uzyskaniem odpowiedzi na leczenie. Analiza molekularna 29 próbek cuSCC/KA w 41\% wykazała mutację HRAS [23].

\section{Opis przypadku 3}

W maju 2009 roku do Centrum Onkologii — Instytutu w Warszawie zgłosiła się 72-letnia kobieta z powodu rozpoznanego czerniaka skóry karku. Zmiana skórna została usunięta poza naszym ośrodkiem, a w dostarczonym badaniu histopatologicznym stwierdzono podtyp guzkowy czerniaka skóry, który został oceniony na pT1b. U chorej wykonano limfoscyntygrafię, uwidaczniając drogi spływu chłonki w kierunku węzłów chłonnych karku obustronnie oraz w kierunku obu okolic nadobojczykowych. Z uwagi na niespecyficzny wychwyt w badaniu odstąpiono od operacji węzła wartowniczego, wykonując jedynie wycięcie blizny po biopsji wycinającej zmiany pierwotnej. Chora do marca 2011 roku pozostawała w obserwacji, kiedy to usunięto zmianę skórną na przedramieniu prawym. Z uwagi na rozpoznanie czerniaka skóry in situ, wykonano radykalne wycięcie blizny po biopsji wycinającej kolejnej zmiany pierwotnej.

Na początku 2013 roku chora leczyła się z powodu zapalenia płuc. W wykonanym konwencjonalnym badaniu radiologicznym oraz TK klatki piersiowej stwierdzono liczne zmiany ogniskowe w płucu prawym odpowiadające przerzutom. Największą zmianę o wymiarach $42 \mathrm{~mm} \times 56 \mathrm{~mm} \times 46 \mathrm{~mm}$ uwidoczniono po stronie prawej na pograniczu jamy brzusznej i klatki piersiowej, ciągnącą się wzdłuż aorty, nieco uciskając ją i prawy przedsionek.

Chora wiele lat wcześniej dwukrotnie przebyła zawał mięśnia sercowego, a od kilku lat leczyła się z powodu nadciśnienia tętniczego. Przyjmowała kwas acetylosalicylowy, amlodypinę, simwastatynę oraz ramipryl w dawkach zaleconych przez kardiologa. Stan ogólnej sprawności chorej był dobry. Nie stwierdzano nieprawidłowości w badaniu przedmiotowym.

Po wykazaniu w materiale $z$ usuniętego czerniaka mutacji w genie BRAF, chora od kwietnia 2013 roku rozpoczęła przyjmowanie wemurafenibu w zaleconej dawce początkowej 960 mg dwa razy dziennie. W pierwszym miesiącu leczenia z uwagi na wystąpienie zapalenia spojówek, zmęczenia 2. stopnia oraz wysypki drobnogrudkowej na twarzy i tułowiu 1. stopnia, zredukowano dawkę dobową wemurafenibu do $1440 \mathrm{mg}$. Spowodowało to ustąpienie zmęczenia przy utrzymaniu się pozostałych działań niepożądanych na takim samym poziomie.

Po dwóch miesiącach od rozpoczęcia leczenia chora przebyła sześciodniową hospitalizację w Klinice Nowotworów Tkanek Miękkich, Kości i Czerniaków z powodu hipokalemii oraz hepatotoksyczności 3. stopnia. Wyniki wybranych parametrów badań laboratoryjnych chorej przedstawiono w tabeli II. Chora zgłaszała osłabienie i zawroty głowy. Oprócz nieprawidłowych wyników badań laboratoryjnych stwierdzono w badaniu przedmiotowym powiększoną wątrobę oraz guzkową zmianę rogowaciejącą na skórze lewej piersi. W badaniach obrazowych stwierdzano odpowiedź na leczenie. Z powodu działań niepożądanych leku zaprzestano podawania wemurafenibu do chwili ich ustąpienia. $U$ chorej zastosowano leczenie wspomagające, obserwując poprawę stanu ogólnego oraz parametrów laboratoryjnych (tab. II). Następnie usunięto zmianę skórną piersi lewej, która okazała się być brodawką łojotokową (verruca seborrhoica).

Po 34 dniach przerwy w przyjmowaniu leku, z uwagi na złagodzenie działań niepożądanych oraz uzyskaną częściową regresję zmian przerzutowych, chora ponownie rozpoczęła terapię wemurafenibem $\mathrm{w}$ dawce $480 \mathrm{mg}$ dwa razy 


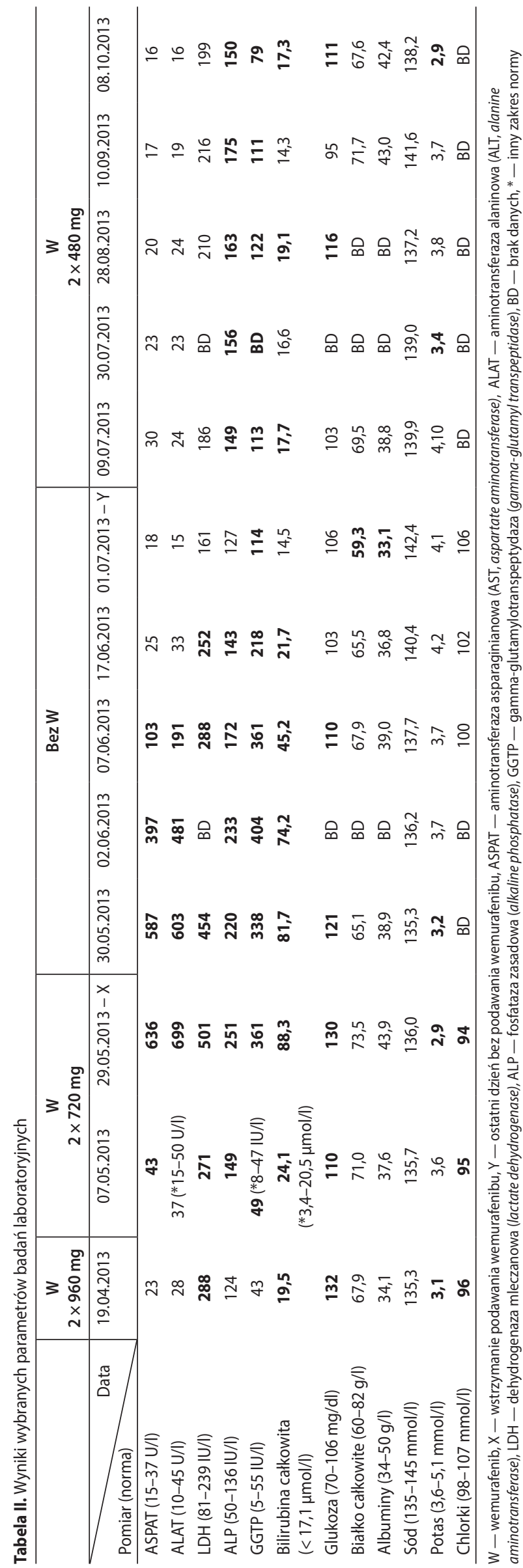

dziennie. W trakcie kontynuowania leczenia obserwowano dalszą regresję zmian przerzutowych, a jedyne działanie niepożądane, na które uskarżała się chora dotyczyło braku łaknienia (stopień 1.). Łącznie chora przyjmowała inhibitor BRAF przez 7 miesięcy, z ponad miesięczną przerwą z powodu objawów ubocznych. Kontynuuje terapię do dnia dzisiejszego.

\section{Omówienie przypadku 3}

$U$ chorych z rozpoznanym i leczonym czerniakiem skóry istnieje blisko 9-krotnie zwiększone ryzyko wystąpienia kolejnego ogniska pierwotnego czerniaka (co obserwowaliśmy u naszej chorej) w porównaniu do ogólnej populacji [24].

Należy również wspomnieć o potencjalnej możliwości pojawienia się nowego pierwotnego ogniska czerniaka u chorych leczonych wemurafenibem. W badaniach klinicznych postępowanie obejmowało wycięcie zmiany, a chorzy kontynuowali leczenie inhibitorem BRAF bez konieczności modyfikacji jego dawki [15]. Podobnie postępuje się w przypadku wystąpienia innych nowych zmian skórnych w trakcie leczenia, w tym brodawki łojotokowej, którą zdiagnozowano u wspomnianej pacjentki. Ponadto należy pamiętać, że u chorych w 65. roku życia i starszych może istnieć większe prawdopodobieństwo wystąpienia działań niepożądanych, w tym rozwoju nowych zmian skórnych, tj. cuSCC [15]. W badaniu III fazy chorzy w tej grupie wiekowej stanowili $28 \%$ $[15,16]$.

Wysypka o małym nasileniu była dobrze tolerowana przez chorą. Pierwsza redukcja dawki była konieczna z powodu wystąpienia znacznego zmęczenia oraz zapalenia spojówek.

Rozwinięcie hepatotoksyczności 3. stopnia wymusiło ponad miesięczną przerwę w ordynowaniu leku. Po powrocie większości parametrów biochemicznych do wartości prawidłowych było możliwe wznowienie leczenia w kolejnej zredukowanej dawce. W dalszej obserwacji uwagę zwracała utrzymująca się zwiększona aktywność GGTP i ALP stopnia 1. (tab. II).

Zwiększenie aktywności enzymów wątrobowych jest znanym powikłaniem terapii. Zależnie od stopnia toksyczności należy postępować zgodnie z wytycznymi zawartymi w tabeli I.Z uwagi na metabolizowanie wemurafenibu przez wątrobę u chorych z umiarkowanymi do ciężkich zaburzeń czynności wątroby może po kilku tygodniach terapii dojść do kumulacji stężenia leku. Dane pochodzące z leczenia tych chorych są ograniczone. Należy zatem szczególnie tę grupę chorych poddać ścisłej obserwacji oraz regularnie wykonywać u nich badanie elektrokardiograficzne, z uwagi na możliwość wydłużenia czasu trwania odstępu QT [15].

Zarówno przy stosowaniu wyższych dawek wemurafenibu, jak i przy 480 mg dwa razy na dobę obserwowano u chorej częściową odpowiedź na leczenie. Istnieją przesłanki z danych klinicznych wskazujące na możliwość uzyska- 
nia korzyści terapeutycznej przez wybranych chorych przy zastosowaniu jeszcze niższych dawek dobowych leku. Nie jest to jednak praktyka powszechnie stosowana i obecnie dopuszczalną najniższą dawką w terapii jest 480 mg dwa razy na dobę $[15,21]$.

\section{Opis przypadku 4}

Kobieta 46-letnia zgłosiła się do Centrum Onkologii — Instytutu po raz pierwszy we wrześniu 2009 roku w celu konsultacji z powodu usuniętej przed miesiącem i potwierdzonej w badaniu histopatologicznym wznowy miejscowej czerniaka skóry podudzia lewego. Z dostarczonej dokumentacji przez chorą ustalono, że zmiana pierwotna czerniaka została wycięta w 2003 roku. Chora nie dysponowała ówczesnym wynikiem badania histopatologicznego. W naszym ośrodku u chorej wykonano wycięcie blizny po usunięciu wznowy miejscowej oraz biopsję węzła wartowniczego, w którym nie znaleziono utkania czerniaka. Jednocześnie usunięto zmianę skóry pośladka, którą w badaniu histopatologicznym oceniono jako znamię błękitne (naevus coeruleus). Chora nie zgłaszała dolegliwości, a w badaniu przedmiotowym uwagę zwracał nieznaczny obrzęk lewej kończyny dolnej, który w trakcie dalszej obserwacji ustąpił. Dwa lata później u chorej wycięto dwie zmiany przerzutowe in-transit z okolicy kolana lewego oraz kolejną wznowę miejscową w bliźnie po usuniętej zmianie pierwotnej. Celem oceny stopnia zaawansowania choroby wykonano u chorej badanie TK głowy, klatki piersiowej, jamy brzusznej i miednicy, uwidaczniając jedynie przerzuty w płucach oraz płyn w lewej jamie opłucnowej. W badaniu przedmiotowym uwagę zwracało zniesienie szmeru pęcherzykowego u podstawy płuca lewego. U chorej kilkakrotnie wykonano torakocentezę oraz zastosowano 4 kursy chemioterapii z udziałem dakarbazyny, po których nastąpiła progresja choroby pod postacią nowych zmian przerzutowych w opłucnej i kościach. Chora zgłaszała kaszel oraz bóle klatki piersiowej po stronie lewej związane z zaawansowaniem choroby. Z tego tytułu otrzymywała odpowiednie leczenie.

Z uwagi na progresję choroby po zastosowaniu chemioterapii oraz pozytywny wynik mutacji w genie BRAF zaproponowano chorej leczenie inhibitorem BRAF.W marcu 2012 roku chora rozpoczęła przyjmowanie wemurafenibu w należnej dawce 960 mg dwa razy dziennie. Dwa tygodnie od zapoczątkowania przyjmowania leku u chorej pojawiła się wysypka drobnogrudkowa w rejonie mieszków włosowych, zaczerwienienie skóry twarzy oraz krótkotrwałe dolegliwości bólowe mięśni i stawów. Wszystkie działania niepożądane oceniono na 1. stopień. Po siedmiu tygodniach przyjmowania wemurafenibu na skórze twarzy stwierdzono u chorej osiem nowych zmian skórnych, które usunięto. W ocenie histopatologicznej rozpoznano raka płaskonabłonkowego in situ (carcinoma planoepitheliale praecipue in situ) oraz rogowacenie łojotokowe (keratosis seborrhoica).
Kilka zmian skóry twarzy poddano laseroterapii poza naszym ośrodkiem. Chora cały czas kontynuowała przyjmowanie inhibitora BRAF w niezmienionej dawce. Nadal utrzymywały się wcześniejsze działania niepożądane na takim samym poziomie oraz w trzecim miesiącu leczenia dołączyła się PPE stopnia 1.

W listopadzie 2012 roku na skórze pleców chorej pojawiła się zmiana skórna w największym wymiarze $5 \mathrm{~cm}$, która okazała się być kaszakiem (atheroma). Po dziewięciu miesiącach leczenia z powodu nieakceptowanego wydłużenia odstępu QTc w kontrolnym badaniu elektrokardiograficznym, wstrzymano podawanie leku. W badaniach laboratoryjnych stwierdzono obniżenie stężenia magnezu w surowicy do wartości 0,64 mmol/l (zakres normy 0,7$-1,0 \mathrm{mmol} / \mathrm{l}$ ). Po 9 dniach przerwy w terapii i uzupełnieniu niedoboru jonu zarejestrowano w badaniu EKG czas trwania odstępu QTc < 450 ms (a jego wzrost oceniono na mniej niż 60 ms w porównaniu do badania wyjściowego), co umożliwiło wznowienie u chorej leczenia w dawkach zredukowanych tj. 720 mg dwa razy dziennie (tab. III). Chora nie miała rozpoznanych innych chorób współistniejących ani nie przyjmowała leków mogących potencjalnie wydłużyć odstęp QT (tab. IV).

Po 2 miesiącach od rozpoczęcia przyjmowania wemurafenibu stwierdzono częściową regresję zmiany naciekowej związanej z opłucną tylnej ściany klatki piersiowej (ryc. 1). Do kwietnia 2013 roku obserwowano dalsze niewielkie zmniejszanie się wspomnianej zmiany. Ogniska przerzutowe w innych lokalizacjach nie wykazywały dynamiki.

W kwietniu 2013 roku chora zgłosiła zawroty głowy, zaburzenia widzenia oraz równowagi. W wykonanym w trybie pilnym badaniu TK głowy stwierdzono trzy przerzuty do lewej półkuli mózgu - w płacie ciemieniowym o wymiarach $53 \times 42 \mathrm{~mm}$ oraz w płacie skroniowym o wymiarach $30 \times 25 \mathrm{~mm}$ i $33 \times 25 \mathrm{~mm}$ z towarzyszącym obrzękiem. Z uwagi na stwierdzenie nowych zmian przerzutowych w mózgu, a także progresji zmian w ścianie klatki piersiowej oraz pogorszeniu stanu ogólnego chorej zdecydowano o zakończeniu leczenia wemurafenibem, po trzynastu miesiącach terapii.

Następnie otrzymała napromienianie na mózgowie w pięciu dawkach frakcyjnych po 400 cGy do łącznej dawki całkowitej wynoszącej 2000 cGy oraz leczenie przeciwobrzękowe. W dalszej kolejności ordynowano chorej chemioterapię wielolekową z udziałem dakarbazyny, uzyskując stabilizację zmian przerzutowych. Odpowiedź na leczenie monitorowano za pomocą badania tomografii komputerowej. Od maja 2013 roku obserwowano stały wzrost aktywności LDH. Pomimo modyfikacji leczenia wspomagającego chora okresowo zgłaszała duszność, zawroty głowy oraz łatwe męczenie. Po pięciu miesiącach leczenia systemowego i przeciwobrzękowego u chorej nastąpiło pogorszenie stanu ogólnego oraz wystąpił epizod utraty przytomności. Obecnie pozostaje pod opieką hospicjum. 
Tabela III. Modyfikacja dawek wemurafenibu zależna od wydłużenia odstępu QT [14]

\begin{tabular}{|c|c|}
\hline QTC & Dawka wemurafenibu \\
\hline$>500$ ms przed leczeniem & Nie zaleca się leczenia \\
\hline $\begin{array}{l}\text { > } 500 \text { ms i jednocześnie odstęp QTc wydłużył się } \\
\text { o ponad } 60 \text { ms w porównaniu z wartościami sprzed } \\
\text { leczenia }\end{array}$ & Zakończyć leczenie \\
\hline $\begin{array}{l}\text { > } 500 \text { ms podczas leczenia i odstęp wydłużył się } \\
\text { o mniej niż } 60 \text { ms w porównaniu z wartościami } \\
\text { sprzed leczenia }\end{array}$ & \\
\hline - pierwszy raz & $\begin{array}{l}\text { 1. Tymczasowo przerwać - do QTc < } 500 \text { ms } \\
\text { 2. Wznowić } 720 \mathrm{mg} \times 2 \text { (lub } 480 \mathrm{mg} \times 2 \text { - jeśli dawka była już zmniejszana) }\end{array}$ \\
\hline - drugi raz & $\begin{array}{l}\text { 1. Tymczasowo przerwać }- \text { do QTc }<500 \text { ms } \\
\text { 2. Wznowić } 480 \mathrm{mg} \times 2 \text { (lub zakończyć }- \text { jeśli dawka była już zmniejszana do } 480 \mathrm{mg} \times 2 \text { ) }\end{array}$ \\
\hline - trzeci raz & Zakończyć leczenie \\
\hline
\end{tabular}

QTc — skorygowany czas trwania odstępu QT (QT corrected)

Tabela IV. Wybrane leki wydłużające czas trwania odstępu QT [27, 28]

\begin{tabular}{|c|c|}
\hline Grupa & Lek \\
\hline Anestetyki & halotan, enfluran, izofluran \\
\hline Antybiotyki i chemioterapeutyki & $\begin{array}{l}\text { ampicylina, azytromycyna, erytromycyna, ketokonazol, klarytromycyna, } \\
\text { metronidazol, mykonazol, pentamidyna, trimetoprim - sulfometoksazol, } \\
\text { ciprofloksacyna, flukonazol, itrakonazol }\end{array}$ \\
\hline Leki przeciwhistaminowe & astemizol, difenhydramina, terfenadyna \\
\hline Diuretyki & indapamid \\
\hline Leki wpływające na przewód pokarmowy i przeciwwymiotne & $\begin{array}{l}\text { cisaprid, dimenhydrynat, domperidon, metoklopramid, granisetron, } \\
\text { ondansetron }\end{array}$ \\
\hline Leki przeciwarytmiczne & amiodaron, chinidyna, dizopiramid, prokainamid, sotalol \\
\hline Leki przeciwdepresyjne i psychotropowe & $\begin{array}{l}\text { amitryptylina, chloropromazyna, desipramina, doksepina, fluoksetyna, } \\
\text { haloperidol, imipramina, risperidon, tiorydazyna, citalopram }\end{array}$ \\
\hline Inne & adrenalina, sildenafil, metadon \\
\hline Leki wykorzystywane w leczeniu chorych na nowotwory złośliwe & $\begin{array}{l}\text { bortezomib, bosutynib, dazatynib, erybulina, kryzotynib, lapatynib, } \\
\text { nilotynib, pazopanib, sorafenib, sunitynib, tamoksyfen, vandetanib, } \\
\text { wemurafenib, vorinostat }\end{array}$ \\
\hline
\end{tabular}

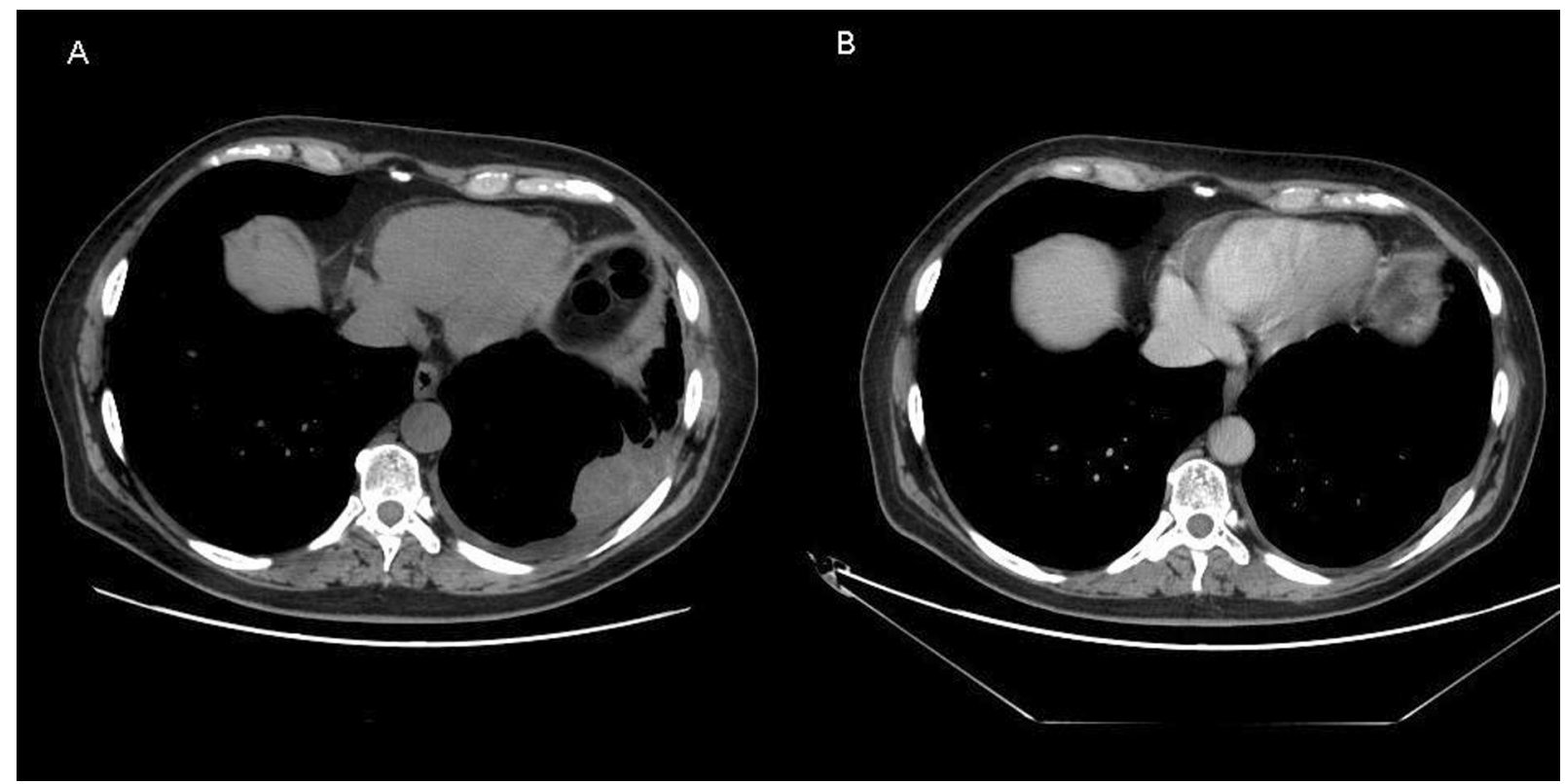

Rycina 1. Obrazy badania tomografii komputerowej klatki piersiowej u chorej przed i w trakcie leczenia wemurafenibem. Obrazy badania tomografii komputerowej klatki piersiowej przedstawiające naciek guzowaty opłucnowy po stronie lewej, A — przed rozpoczęciem leczenia wemurafenibem, B - po dwóch miesiącach przyjmowania wemurafenibu (częściowa regresja zmiany) 


\section{Omówienie przypadku 4}

Zmiany hiperkeratotyczne występują u około 24-29\% chorych w trakcie leczenia wemurafenibem i nie wymagają modyfikacji dawki [15, 25-27]. U chorych leczonych wemurafenibem należy pamiętać o możliwości wystąpienia cuSCC oraz raka płaskonabłonkowego w innej lokalizacji niż skóra (non-cuSCC, non-cutaneous squamous cell carcinoma). Należy starannie badać chorego celem wykrycia cuSCC co miesiąc w trakcie leczenia inhibitorem BRAF oraz do sześciu miesięcy po zakończeniu terapii. Podobnie, w celu poszukiwania non-cuSCC należy przynajmniej dokonywać wzrokowej oceny błon śluzowych jamy ustnej i badania przedmiotowego węzłów chłonnych przed rozpoczęciem leczenia, co trzy miesiące w trakcie terapii i do sześciu miesięcy po jej zakończeniu [15]. Ponadto, oprócz wykonywania badania TK klatki piersiowej, zalecane jest okresowe badanie chorego przez odbytnicę oraz badanie ginekologiczne u kobiet [15]. Mediana czasu od rozpoczęcia leczenia do pojawienia się zmian skórnych o typie SCC wynosi 7-8 tygodni (zakres 2-36 tygodni) $[25,28]$. U około $33 \%$ chorych raportowano pojawienie się kolejnych zmian skórnych, a mediana czasu, pomiędzy którymi występowały nowe ogniska wynosiła 6 tygodni [28]. U opisywanej chorej powstałe zmiany skórne nie zmuszały do modyfikacji leczenia.

Istotnym natomiast działaniem niepożądanym, które warunkowało wstrzymanie terapii było wydłużenie odstępu QTc. Odstęp QT obejmuje czas trwania depolaryzacji (zespół QRS) i repolaryzacji (odcinek ST i załamekT) komórek mięśnia sercowego. Wydłużenie odstępu QT świadczy o spowolnieniu procesu repolaryzacji, co oznacza, że opóźniony jest powrót do spoczynkowej wartości potencjału błonowego po zakończeniu depolaryzacji kardiomiocytów [29]. Sprzyja to wystąpieniu wczesnych potencjałów następczych (EADs, early afterdepolarizations), które mogą wyzwalać arytmie [29]. Wydłużenie odstępu QT może prowadzić do zwiększenia ryzyka wystąpienia komorowych zaburzeń rytmu, w tym zaburzeń typu torsade de pointes [15]. Nie zaleca się leczenia wemurafenibem u chorych z zespołem wydłużonego QT przyjmujących produkty lecznicze potencjalnie wydłużające odstęp QT lub u których nie można wyrównać zaburzeń elektrolitowych (tab. IV) [15, 30]. Zgodnie z zaleceniami należy w określonych przedziałach czasowych wykonywać badanie elektrokardiograficzne oraz oznaczać stężenia elektrolitów (w tym magnezu). U naszej chorej po wydłużeniu odstępu QTc zaprzestano ordynowania leku. Następnie z uwagi na jego zmniejszenie w kontrolnym badaniu elektrokardiograficznym oraz ocenienie jego wydłużenia na mniej niż 60 ms w porównaniu do wartości sprzed leczenia, zgodnie z zaleceniami ponownie włączono wemurafenib w dawce zredukowanej (tab. III).

Uwagę zwraca długo utrzymująca się u chorej odpowiedź na leczenie. $Z$ dostępnych danych wiemy, że po ok. 6-7 miesiącach od rozpoczęcia terapii dochodzi do progresji choroby [1]. Związane jest to z aktywacją mechanizmów oporności na lek [1]. U naszej chorej progresja choroby wystąpiła po 13 miesiącach leczenia inhibitorem BRAF.

\section{Opis przypadku 5}

W lipcu 1995 roku do Klinki Nowotworów Tkanek Miękkich, Kości i Czerniaków zgłosiła się 28-letnia kobieta, u której miesiąc wcześniej usunięto zmianę skórną okolicy ciemieniowej prawej. W dostarczonym raporcie histopatologicznym stwierdzono podtyp czerniaka szerzącego się powierzchownie (SSM - superficial spreading melanoma), brak owrzodzenia w badanym materiale, grubość nacieku 0,9 mm według Breslowa oraz Il poziom głębokości naciekania według Clarka. Chorą poddano wieloletniej obserwacji w naszym ośrodku, w trakcie której okresowo usuwano kolejne zmiany skórne głowy - znamię soczewicowate złożone, znamię skórne złożone oraz znamię łączące (naevus lentiginalis compositus, naevus compositus cutis, naevus junctionalis).

Po siedemnastu latach od usunięcia zmiany pierwotnej, u chorej w okolicy karku po stronie prawej stwierdzono około $1 \mathrm{~cm}$ guzek. W pozostałym badaniu przedmiotowym nie odnotowano istotnych odchyleń od stanu prawidłowego, w tym nie uchwycono cech przemawiających za wznową miejscową w bliźnie po usuniętym czerniaku. Badanie ultrasonograficzne szyi wykonano dwukrotnie w odstępie trzymiesięcznym, uwidaczniając węzeł chłonny karkowy po stronie prawej o jednakowych wymiarach $6 \times 3 \mathrm{~mm}$, który odpowiadał wyczuwalnemu guzkowi w okolicy karku. W otrzymanych wynikach BAC wspomnianej zmiany nie zidentyfikowano komórek nowotworowych. Sześć miesięcy później zmiana nie była uchwytna w badaniu przedmiotowym.

W wieku 46 lat u chorej nastąpiło uogólnienie choroby. Chora zgłaszała zaburzenia równowagi, bóle głowy oraz okresową duszność. Z nieprawidłowości w badaniu przedmiotowym stwierdzono osłuchowo trzeszczenia nad polami płucnymi. W badaniu pozytonowej tomografii emisyjnej połączonej z tomografią komputerową (PET-CT — positron emission tomography-computed tomography) uwidoczniono przerzuty do mózgu, węzłów chłonnych śródpiersia, płuc, wątroby, powłok jamy brzusznej i kości. W obrazowaniu metodą rezonansu magnetycznego (MRI - magnetic resonance imaging) głowy wykonanym w styczniu 2013 roku uwidoczniono liczne, różnej wielkości zmiany o charakterze przerzutów w obu półkulach mózgu (tab. V) (ryc. 2).

Chora otrzymała napromienianie na mózgowie w 5 dawkach frakcyjnych po 400 cGy do dawki całkowitej 2000 cGy oraz adekwatne leczenie wspomagające, uzyskując poprawę stanu ogólnego. Po zidentyfikowaniu w materiale histopatologicznym czerniaka mutacji w kodonie V600 BRAF, w lutym 2013 roku chora rozpoczęła przyjmowanie wemurafenibu w dawce należnej 960 mg dwa razy dziennie. 
Tabela V. Porównanie wymiarów zmian przerzutowych w mózgu u chorej w trakcie leczenia wemurafenibem

\begin{tabular}{|c|c|c|c|c|}
\hline & Bez W & $\begin{array}{l}\text { Po } 7 \text { tygodniach } \\
\text { przyjmowania } \\
\mathrm{W}^{1} 720 \mathrm{mg} \times 2\end{array}$ & W $720 \mathrm{mg} \times 2$ & Kontynuacja W \\
\hline $\begin{array}{lr}\text { Lokalizacja } & \begin{array}{r}\text { Wykonane } \\
\text { badanie } \\
\text { zmiany } \\
\text { przerzutowej w OUN }\end{array} \\
\end{array}$ & $\begin{array}{l}\text { MRI głowy } \\
\text { Badanie nr } 1 \\
\text { Styczeń } 2013\end{array}$ & $\begin{array}{c}\text { MRI głowy } \\
\text { Badanie nr } 2 \\
\text { Kwiecień } 2013\end{array}$ & $\begin{array}{c}\text { MRI głowy } \\
\text { Badanie nr } 3 \\
\text { Czerwiec } 2013\end{array}$ & $\begin{array}{l}\text { MRI głowy } \\
\text { Badanie nr } 4 \\
\text { Październik } 2013\end{array}$ \\
\hline $\begin{array}{l}\text { W płacie potylicznym prawej półkuli } \\
\text { mózgu }\end{array}$ & $46 \times 44 \times 24 \mathrm{~mm}$ & $\begin{array}{c}27 \times 20 \times 33 \mathrm{~mm} \\
\left(27 \times 21 \mathrm{~mm}^{*}\right)\end{array}$ & $23 \times 20 \mathrm{~mm}$ & \multirow{4}{*}{$\begin{array}{l}\text { W obu półkulach mózgu } \\
\text { i moście po stronie lewej } \\
\text { Ogniska o średnicy od } 10 \\
\text { do } 25 \mathrm{~mm} \\
\text { Część ognisk - cechy } \\
\text { ukrwotocznienia }\end{array}$} \\
\hline $\begin{array}{l}\text { Na pograniczu płata skroniowego } \\
\text { i ciemieniowego po stronie prawej }\end{array}$ & $39 \times 44 \times 36 \mathrm{~mm}$ & $\begin{array}{c}30 \times 28 \times 36 \mathrm{~mm} \\
\left(30 \times 25 \mathrm{~mm}^{*}\right)\end{array}$ & $27 \times 21 \mathrm{~mm}$ & \\
\hline $\begin{array}{l}\text { Przy rogu przednim komory bocznej } \\
\text { prawej }\end{array}$ & $19 \times 29 \times 29 \mathrm{~mm}$ & $\begin{array}{l}19 \times 20 \times 16 \mathrm{~mm} \\
\left(19 \times 16 \mathrm{~mm}^{*}\right)\end{array}$ & $12 \times 10 \mathrm{~mm}$ & \\
\hline Liczne drobne lite zmiany meta & śr. do 13 mm & śr. do 5-6 mm & śr. 4-5 mm & \\
\hline
\end{tabular}

W - wemurafenib (vemurafenib), ${ }^{1}$ trzy pierwsze dni przyjmowała wemurafenib w dawce $960 \mathrm{mg} \times 2$, MRI — obrazowanie metodą rezonansu magnetycznego (magnetic resonance imaging), OUN — ośrodkowy układ nerwowy, * pomiary dla drugiego badania zweryfikowane przez radiologa opisującego badanie numer 3
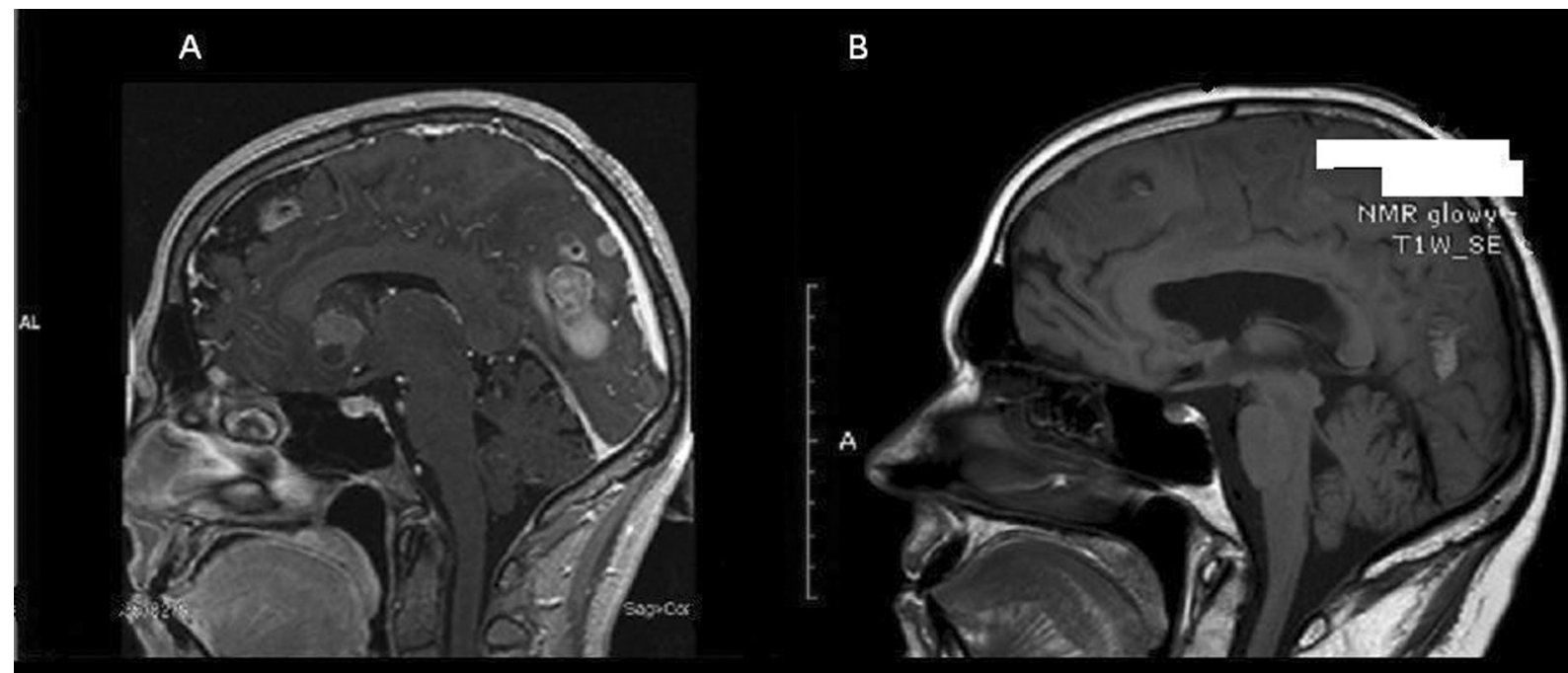

A

B

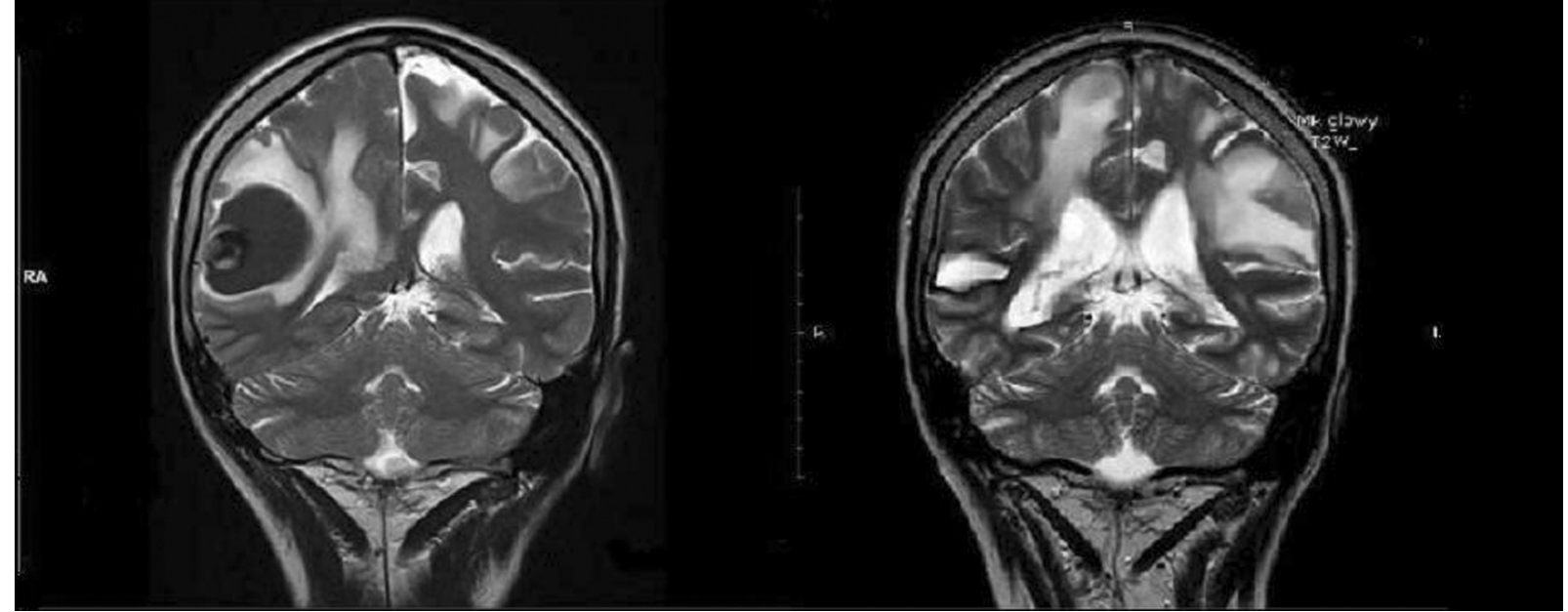

Rycina 2. Obrazowanie metodą rezonansu magnetycznego (MRI) głowy u chorej przed i w trakcie leczenia wemurafenibem. MRI głowy wykazujące zmiany przerzutowe do mózgu A — przed rozpoczęciem leczenia wemurafenibem, B - po 8 miesiącach leczenia wemurafenibem (częściowa remisja zmian stwierdzanych w badaniu A) 
W trzecim dniu leczenia chora w stanie ogólnym średnim została przyjęta w trybie pilnym do Kliniki Nowotworów Tkanek Miękkich, Kości i Czerniaków z powodu silnych, utrzymujących się od doby, dolegliwości bólowych nadbrzusza i śródbrzusza nieustępujących po lekach przeciwbólowych i rozkurczowych. Chora negowała błąd dietetyczny. Cztery lata wcześniej przebyła ostre zapalenie trzustki o nieznanej etiologii (aczkolwiek wówczas chora podawała spożycie alkoholu). Obecnie dodatkowo przyjmowała 9 mg deksametazonu dziennie. W wykonanym badaniu ultrasonograficznym jamy brzusznej uwidoczniono niewielką ilość wolnego płynu wokół wątroby, śledziony i międzypętlowo, w VII segmencie wątroby hiperechogeniczną niejednorodną $16 \mathrm{~mm}$ zmianę ogniskową, obrzękniętą trzustkę z niejednorodnym miąższem oraz płynową otoczką wokół niej, a w okolicy pnia trzewnego węzeł chłonny o wymiarach $20 \times 9 \mathrm{~mm}$. W badaniu TK jamy brzusznej oprócz $23 \mathrm{~mm}$ zmiany w segmencie VII o charakterze przerzutu wykazano niejednoznaczne 3-4 mm zmiany, ponadto zobrazowano ogniska przerzutowe w otrzewnej, naciekowo-wysiękowe oraz płyn w jamie otrzewnowej. Wielkość i kształt trzustki oceniono jako prawidłowe, bez zmian ogniskowych i zwapnień w jej obrębie jednak z masywnym naciekiem wokół niej. Radiolog na podstawie uzyskanego obrazu poza zmianami przerzutowymi nie wykluczał komponentu zapalnego wokół trzustki. Ponadto stwierdzono niewielką ilość płynu w lewej jamie opłucnowej.

W dniu przyjęcia do szpitala, w badaniach laboratoryjnych uwagę zwracała leukocytoza, hiperglikemia, podwyższona aktywność LDH 315 IU/I (norma 81-238 IU/l), enzymów trzustkowych w tym amylazy w surowicy - 2352 IU/I (norma < 115 IU/l) i w moczu - 22889 IU/I (norma < 400 IU/l) oraz zwiększone stężenie mocznika. W kolejnym dniu dodatkowo obserwowano hipokalcemię, hipoalbuminemię oraz zwiększenie stężenia białka C-reaktywnego (CRP — C-reactive protein). Wstrzymano podawanie wemurafenibu na 2 dni oraz zastosowano adekwatne do sytuacji klinicznej leczenie, uzyskując szybką poprawę stanu ogólnego, ustąpienie dolegliwości bólowych oraz normalizację parametrów laboratoryjnych, w tym stałe zmniejszanie aktywności amylazy we krwi i moczu (odpowiednio 325 IU/l i 293 IU/I). W szóstej dobie hospitalizacji chora została wypisana do domu z zaleceniem przyjmowania wemurafenibu w dawce $720 \mathrm{mg}$ dwa razy dziennie. Nie obserwowano nawrotu dolegliwości bólowych brzucha oraz wzrostu aktywności enzymów trzustkowych po wznowieniu leczenia.

W pierwszym miesiącu terapii odnotowano u chorej wystąpienie wysypki drobnogrudkowej na twarzy i górnej części klatki piersiowej. W trzecim miesiącu leczenia do wysypki dołączył się świąd skóry oraz obrzęk błon śluzowych jamy ustnej. Po tygodniu przerwy w przyjmowaniu inhibitora BRAF i zmniejszeniu nasilenia działań niepożądanych powrócono do terapii. W 14 tygodniu leczenia ze skóry uda lewego usunięto brodawkę łojotokową (verruca seborrhoica).

W kolejnych badaniach TK klatki piersiowej, jamy brzusznej i miednicy oraz MRI głowy wykonywanych co dwa miesiące obserwowano częściową odpowiedź na leczenie. W badaniach wykonanych po 7 tygodniach przyjmowania inhibitora BRAF opisano znaczne zmniejszenie zmian przerzutowych w mózgu, płucach i węzłach chłonnych śródpiersia, nie stwierdzano zmian ogniskowych w wątrobie oraz w obrzękniętej trzustce (tab. V). W kolejnych badaniach obserwowano ich dalszą regresję. W tabeli V zestawiono wyniki badań MRI głowy chorej, w których opisywano stopniowe zmniejszanie się zmian przerzutowych w mózgu w trakcie leczenia wemurafenibem. Od marca 2013 roku obserwowano stały wzrost aktywności LDH do wartości maksymalnej wynoszącej $316 \mathrm{IU} / \mathrm{l}$.

W październiku 2013 roku u chorej wystąpił napad padaczkowy ogniskowy wtórnie uogólniony i niedowład połowiczy lewostronny. W badaniu TK mózgu wykonanym w dniu przyjęcia do oddziału neurologicznego uwidoczniono mnogie ogniska najprawdopodobniej o charakterze przerzutowym zlokalizowane obustronnie w płatach czołowych, ciemieniowych, skroniowych i w konarze środkowym móżdżku, ponadto stwierdzono obrzęk obu półkul mózgu. Zintensyfikowano leczenie przeciwobrzękowe u chorej oraz wdrożono leczenie przeciwpadaczkowe, nie obserwując kolejnych napadów padaczkowych. Chora w stanie ogólnym średnim z niedowładem połowiczym lewostronnym została przekazana do naszego ośrodka, gdzie otrzymała drugi etap radioterapii paliatywnej oraz kontynuację leczenia wspomagającego. Z uwagi na progresję choroby oraz znaczne pogorszenie stanu ogólnego chorej zakończono leczenie wemurafenibem. Chora przyjmowała inhibitor BRAF przez osiem miesięcy, a obecnie pozostaje pod opieką hospicjum.

\section{Omówienie przypadku 5}

Uzyskana odpowiedź na leczenie u chorej świadczy o zasadności zastosowania wemurafenibu także u chorych z lokalizacją zmian przerzutowych w mózgu (tab. V) (ryc. 2). Poza jednym epizodem ostrego zapalenia trzustki (OZT), którego ze względu na inne przesłanki, nie można jednoznacznie powiązać ze stosowaniem wemurafenibu chora dość dobrze tolerowała leczenie.

Dotychczasowe dane przemawiają za stosowaniem wemurafenibu u chorych z masywnymi zmianami przerzutowymi, ze względu na możliwie szybkie uzyskanie ich zmniejszenia oraz poprawę stanu ogólnego, co obserwowaliśmy u naszej chorej. Niestety po pewnym czasie dochodzi do oporności na leczenie. U pacjentki w dziewiątym miesiącu leczenia doszło do progresji choroby oraz pogorszenia stanu ogólnego. Podkreślić należy, że ogniska przerzutowe w OUN opisywane w badaniu sprzed leczenia ulegały sukcesywnemu zmniejszaniu w trakcie przyjmowania inhibitora BRAF, 
a progresja choroby w OUN miała miejsce przede wszystkim pod postacią pojawienia się nowych zmian (tab. V) (ryc. 2). Opisywany przebieg leczenia chorej i uzyskane wyniki są spójne z doniesieniami w piśmiennictwie światowym.

W przeprowadzonych badaniach z udziałem wemurafenibu, aktywne przerzuty do OUN były kryterium wykluczającym. Rochet i wsp. oraz Dummer i wsp. wskazali na możliwą skuteczność tego leku u chorych z przerzutami do mózgu [31, 32]. W obecnie obowiązującym programie lekowym w Polsce możliwe jest zastosowanie wemurafenibu u chorych przy braku objawowych przerzutów do OUN lub w stanie bezobjawowym po przebytym leczeniu chirurgicznym lub radioterapii przerzutów w mózgu [21].

U chorej odnotowano przejściowy wzrost aktywności LDH, który mógł być spowodowany chorobą podstawową, jak i towarzyszyć OZT. Miesiąc później obserwowano stały wzrost aktywności LDH.

Największą czułość i swoistość w rozpoznawaniu OZT wykazuje oznaczenie lipazy we krwi (nieoznaczane w ośrodku). Przydatne jest oznaczenie amylazy we krwi i moczu. Aktywność amylazy we krwi po upływie 48-72 godzin często wraca do normy mimo trwania choroby. Utrzymuje się zwiększona aktywność amylazy całkowitej w moczu i aktywność izoenzymu trzustkowego we krwi [33]. Badania laboratoryjne odzwierciedlające ciężkość OZT lub wystąpienie powikłań to między innymi: leukocytoza i przesunięcie w lewo wzoru odsetkowego, zwiększone stężenie CRP, prokalcytoniny (PCT), mocznika w surowicy mogące wskazywać na niedostateczną resuscytację płynową lub pogorszenie czynności nerek, ponadto zwiększona aktywność ALT, AST, ALP, wspomnianego LDH. Podstawowym badaniem u chorego jest wykonanie badania ultrasonograficznego jamy brzusznej, a w celu rozpoznania OZT i oceny zakresu zmian w jamie brzusznej powinno się wykonać TK jamy brzusznej najlepiej nie wcześniej niż przed upływem 3. doby. Należy pamiętać, że martwica trzustki rozwija się u większości w ciągu 72 godzin [33]. U chorej wykonana TK jamy brzusznej miała miejsce w 4. dobie od wystąpienia pierwszych objawów.

Objawy, wywiad przebytego OZT, przyjmowanie kortykosteroidów, wyniki badań laboratoryjnych oraz obrazowych przemawiały za stanem zapalnym toczącym się w obrębie trzustki. Po zastosowaniu leczenia adekwatnego dla rozpoznania OZT uzyskano szybką poprawę stanu ogólnego, co umożliwiło powrót do leczenia inhibitorem BRAF. Nie obserwowano ponowienia dolegliwości w trakcie kontynuowania terapii.

Wzrost aktywności enzymów trzustkowych i stany zapalne trzustki nie są charakterystyczne dla działań niepożądanych wemurafenibu [15]. Dotychczas w literaturze jest dostępny jeden opis przypadku wystąpienia OZT u chorego przyjmującego wemurafenib, do którego doszło po dwóch tygodniach terapii [34]. Należy zatem pamiętać, że wemu- rafenib jest względnie nowym lekiem, a w piśmiennictwie pojawiają się doniesienia o nowych wcześniej nieraportowanych działaniach niepożądanych leku [19, 34].

\section{Opis przypadku 6}

W listopadzie 2012 roku 43-letni mężczyzna zgłosił się do Ambulatorium Kliniki Nowotworów Tkanek Miękkich, Kości i Czerniaków z powodu czerniaka skóry.

Miesiąc wcześniej chory przeszedł zabieg wycięcia zmiany pierwotnej i węzłów chłonnych pachy lewej z powodu dodatniej biopsji węzła wartowniczego. W badaniu histopatologicznym stwierdzono postać guzkową czerniaka z owrzodzeniem, grubość nacieku według Breslowa 5 mm, indeks mitotyczny 50/10 HPF (pT4b). Mikroskopowo stwierdzono przerzuty w 10 na 26 węzłów chłonnych, bez przekraczania torebki węzłów (N3). W badaniu molekularnym wykryto mutację V600E w eksonie 15. genu BRAF.

Z uwagi na wysokie ryzyko nawrotu choroby pacjent znajdował się w ścisłej obserwacji. Już w marcu 2013 roku w kontrolnym badaniu TK klatki piersiowej stwierdzono w płucach liczne mnogie zmiany o charakterze przerzutowym wielkości do $6 \mathrm{~mm}$. Z uwagi na brak mierzalnych zmian przerzutowych według kryteriów RECIST chory nie kwalifikował się do leczenia wemurafenibem w ramach programu lekowego. Wobec powyższego zaproponowano choremu chemioterapię opartą na dakarbazynie, na którą pacjent nie wyraził zgody. W maju 2013 roku doszło do powstania nowych guzków przerzutowych w lewym dole pachowym wielkości do $2 \mathrm{~cm}$. W ramach kwalifikacji do programu lekowego wykonano badanie TK głowy, które uwidoczniło 5 zmian przerzutowych w obrębie mózgowia wielkości 4-16 mm. Przeprowadzono paliatywną radioterapię na obszar mózgowia we frakcjach po 400 cGy do łącznej dawki 2000 cGy. W badaniu TK klatki piersiowej i jamy brzusznej z miednicą stwierdzono zmiany przerzutowe w płucach (6-9 mm), w dole pachowym lewym (43 $\mathrm{mm}$ ) oraz nadnerczach (8 i 21 mm). W czerwcu 2013 roku chory rozpoczął terapię wemurafenibem w dawce 1920 mg/dobę; w chwili rozpoczęcia leczenia chory był w dobrym stanie ogólnym, bez chorób towarzyszących. W wykonanych przed rozpoczęciem terapii badaniach (morfologia krwi, biochemiczne parametry funkcji nerek i wątroby, elektrolity, echo serca, EKG) nie stwierdzono istotnych odchyleń. W drugim miesiącu terapii chory skarżył się na brak apetytu (stopień 2.), zaburzenia smaku (stopień 1.) oraz ogólne osłabienie (stopień 1.). W badaniu fizykalnym zwracała uwagę suchość skóry (stopień 2.) oraz wysypka drobnogrudkowa (stopień 1.). W celu oceny odpowiedzi na leczenie wykonywano badania obrazowe co 8-10 tygodni. W badaniu TK wykonanym po 16 tygodniach terapii stwierdzono znaczną regresję wszystkich zmian przerzutowych. W obrębie mózgowia widoczne były tylko 4 zmiany wielkości 2,5-8 $\mathrm{mm}$. Nie uwidoczniono zmiany przerzutowej w nadnerczu prawym, zmiana w le- 
wym nadnerczu uległa zmniejszeniu o połowę. Również o 50\% zmniejszyły się zmiany w lewym dole pachowym oraz guzki w płucach. Obecnie chory kontynuuje ósmy miesiąc terapii wemurafenibem w pełnej dawce. Chory jest w dobrym stanie ogólnym. Poza drobnogrudkową wysypką oraz suchą skórą w 1. stopniu nasilenia nie stwierdza się innych działań niepożądanych. W aktualnym badaniu TK nadal utrzymuje się regresja zmian przerzutowych.

\section{Opis przypadku 7}

W lipcu 2013 roku do Poradni Kliniki Nowotworów Tkanek Miękkich, Kości i Czerniaków zgłosiła się 77-letnia kobieta z powodu rozsianego czerniaka skóry ramienia lewego. W grudniu 2007 roku chora przeszła zabieg wycięcia zmiany pierwotnej. W badaniu histopatologicznym stwierdzono postać powierzchowną epitelioidnego czerniaka, z owrzodzeniem, a grubość nacieku wg klasyfikacji Breslow wynosiła 0,7 mm (pT1b). W lipcu 2008 roku przeprowadzono limfadenektomię pachową lewostronną z powodu klinicznych przerzutów do węzłów chłonnych pachowych lewych. Mikroskopowo stwierdzono przerzuty w 5/16 węzłów chłonnych, z zatorami w naczyniach limfatycznych torebek (N3). Pięć lat później badanie TK klatki piersiowej wykonane z powodu nawracającego zapalenia płuc uwidoczniło liczne zmiany przerzutowe w płucach wielkości do $22 \mathrm{~mm}$ oraz pojedyncze zmiany przerzutowe w żebrach. W momencie zgłoszenia się do Centrum Onkologii — Instytutu chora była w dobrym stanie sprawności, bez dolegliwości, bez chorób towarzyszących. W wykonanych badaniach laboratoryjnych nie stwierdzono żadnych odchyleń, a w badaniu TK głowy i jamy brzusznej z miednicą nie znaleziono zmian przerzutowych. Badanie molekularne wykazało obecność mutacji w kodonie V600 BRAF. Wobec powyższego chora została zakwalifikowana do leczenia wemurafenibem w ramach programu lekowego. Terapię rozpoczęto w lipcu 2013 roku. W drugim tygodniu leczenia wystąpiła u chorej wysypka (stopień 3.) w postaci zlewających się zmian rumieniowych obejmujących kończyny górne i dolne oraz tułów (ryc. 3). Zgodnie z charakterystyką produktu leczniczego przerwano terapię wemurafenibem i zastosowano doustną sterydoterapię, uzyskując szybką poprawę stanu skóry — zblednięcie i przebarwienie wykwitów. Po złagodzeniu objawów do 1. stopnia włączono ponownie terapię wemurafenibem w dawce zredukowanej o 25\%. Po 10 dniach leczenia wemurafenibem w obniżonej dawce ( $1440 \mathrm{mg} /$ dobę) wysypka uległa nasileniu do 2. stopnia, ponadto towarzyszyło jej ogólne osłabienie (stopień 2.), nudności (stopień 2.) oraz zaburzenia smaku (stopień 1.). Powtórnie wstrzymano terapię. Po 14 dniach przerwy w leczeniu stan chorej uległ poprawie, ustąpiły nudności oraz ogólne osłabienie, wysypka obecna była tylko na ramionach. Redukcja dawki dobowej leku o kolejne 480 mg przyniosła poprawę tolerancji leczenia. W pierwszej ocenie odpowiedzi na leczenie wykonanej po 8 tygodniach terapii stwierdzono częściową odpowiedź na leczenie. W jedenastym tygodniu terapii chora zgłosiła się na nieplanową wizytę zaniepokojona szybko rosnącymi zmianami na skórze twarzy. Z powodu podejrzenia raka skóry zakwalifikowano chorą do zabiegu wycięcia zmian. Z uwagi na liczne zmiany hiperkeratotyczne na skórze kończyn dolnych zastosowano również elektrokoagulację. W badaniu mikroskopowym usuniętych zmian skóry twarzy stwierdzono dwa ogniska raka płaskonabłonkowego G1. Zmiany skórne o typie keratoacanthoma i raka płaskonabłonkowego nie wymagają modyfikacji leczenia, toteż chora kontynuowała terapię wemurafenibem w dotychczasowej dawce. Od chwili rozpoczęcia leczenia wemurafenibem upłynęło 7 miesięcy; chora jest w dobrym stanie ogólnym, poza rogowaceniem naskórka i licznymi zmianami hiperkeratotycznymi nie stwierdza się innych działań niepożądanych. Ostatnie badanie TK wykonane w 26. tygodniu leczenia nie wykazało cech progresji choroby nowotworowej.

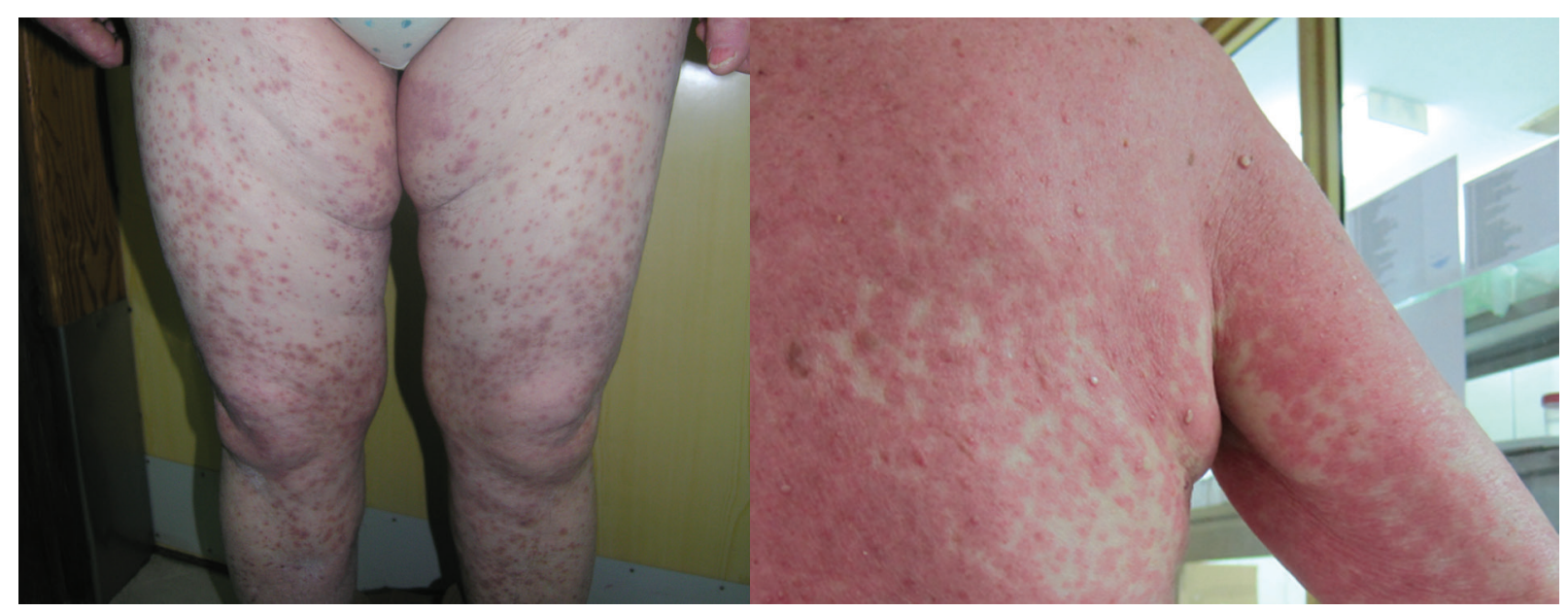

Rycina 3. Zmiany skórne u chorej w trakcie leczenia wemurafenibem 


\section{Opis przypadku 8}

Mężczyzna w wieku 42 lat zgłosił się do Poradni Chirurgii Onkologicznej z powodu nowej zmiany barwnikowej skóry zlokalizowanej na tylnej powierzchni uda, którą zauważył po powrocie z wakacji w Egipcie. W czerwcu 2012 roku u pacjenta wykonano biopsję wycinającą podejrzanej zmiany. Po potwierdzeniu czerniaka w badaniu histopatologicznym, chorego poddano zabiegowi chirurgicznemu polegającemu na doszczętnym wycięciu blizny po wykonanej biopsji wycinającej zmiany pierwotnej z odpowiednimi marginesami wynikającymi z rozpoznania pierwotnego czerniaka skóry. Jednoczasowo przeprowadzono biopsję węzła wartowniczego w lewej pachwinie, który usunięto wraz z węzłem chłonnym towarzyszącym. Stopień zaawansowania choroby oceniono jako T2a N2a M0 według TNM American Joint Committee on Cancer/ Union Internationale Contre le Cancer (AJCC/UICC z 2010 roku). Chorego nie zakwalifikowano do leczenia uzupełniającego. Pacjent zgłaszał się co 3 miesiące na badania kontrolne. W maju 2013 roku, w badaniu ultrasonograficznym stwierdzono dwa lite ogniska na tylno-przyśrodkowej powierzchni lewego uda. Wykonano biopsję, uzyskując obraz cytologiczny odpowiadający komórkom czerniaka. Pacjenta zakwalifikowano do zabiegu operacyjnego. W czerwcu 2013 roku usunięto fragment tkankowy o wymiarach $14 \times 6 \times 4 \mathrm{~cm}$, pokryty skórą o wym. $14 \times 1,5 \mathrm{~cm}$; na przekroju widoczne były dwa ciemnobrązowe guzki in-transit o średnicy 2,5 oraz 1,5 cm. Odległość między guzkami wynosiła $2 \mathrm{~cm}$, a minimalny margines $w$ dnie $0,1 \mathrm{~cm}$. Oceniono, że wycięcie z powięzią zostało przeprowadzone z zachowaniem marginesu niezmienionych tkanek.

W lipcu 2013 roku w badaniu PET-CT stwierdzono aktywny proces nowotworowy w węzłach chłonnych pachwinowych po stronie lewej oraz w płucach. Badanie TK wykazało liczne zmiany o typie przerzutów w obu płucach, w wątrobie oraz pakiet węzłowy w lewej okolicy pachwinowej. W badaniach laboratoryjnych aktywność LDH była w normie. Wysłano tkankę nowotworową ze zmiany pierwotnej na skórze do analizy molekularnej, w której stwierdzono obecność mutacji w kodonie V600 genu BRAF. Ze względu na potwierdzony rozsiew czerniaka oraz obecność mutacji $B R A F$, zakwalifikowano chorego do terapii wemurafenibem w ramach programu lekowego NFZ. We wrześniu 2013 roku chory rozpoczął I cykl leczenia w rekomendowanej dawce 960 mg/2 razy na dobę ( 4 tabl. po 240 mg $2 \times$ dziennie). Po czterech tygodniach pacjent zgłosił się na II kurs leczenia. W badaniach laboratoryjnych obserwowano wzrost aktywności ALT (stopień 3.) oraz AST (stopień 2.) przy prawidłowych wartościach stężenia bilirubiny (ryc. 4 oraz 5) w osoczu. Pacjent nie zgłaszałżadnych dolegliwości, nie obserwowano innych objawów toksyczności wemurafenibu.

Zgodnie z charakterystyką produktu leczniczego preparatu wemurafenibu, zmodyfikowano dawkowanie w oparciu o stopień działań niepożądanych. Ponieważ było to pierw-

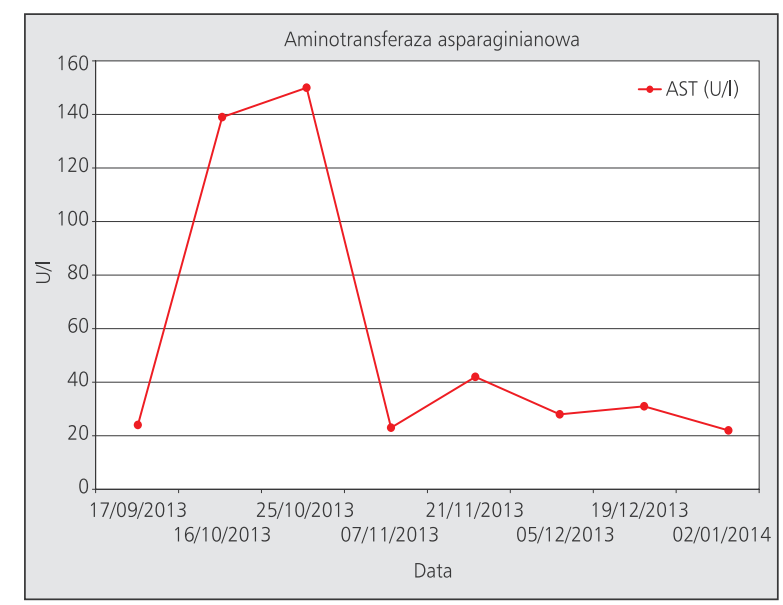

Rycina 4. Aktywność osoczowa aminotransferazy asparaginianowej w trakcie leczenia wemurafenibem

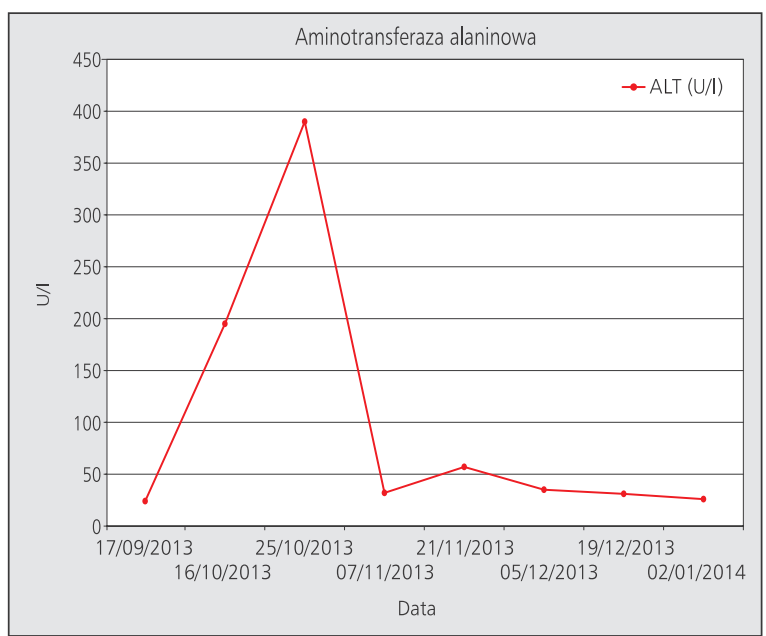

Rycina 5. Aktywność osoczowa aminotransferazy alaninowej w trakcie leczenia wemurafenibem

sze wystąpienie działania niepożądanego w stopniu 2. i 3., przerwano leczenie do wycofania się objawów hepatotoksyczności, które nastąpiło po około dwóch tygodniach od wstrzymania podawania leku. W listopadzie 2013 roku po normalizacji aktywności aminotransferaz wznowiono terapię, redukując dawkę wemurafenibu do 720 mg podawanej $2 \times$ dziennie. Po drugim kursie leczenia wykonano kontrolne badanie TK, w którym stwierdzono stabilizację choroby. Kontynuowano leczenie w zredukowanej dawce, nie obserwowano ponownego wzrostu aktywności aminotransferaz.

W styczniu 2014 roku pacjent trafił do Oddziału Neurologii z objawami sugerującymi przerzuty do ośrodkowego układu nerwowego (OUN); u chorego występowały bóle głowy, zaburzenia zachowania oraz poranne nudności. W badaniach obrazowych potwierdzono obecność mnogich ognisk przerzutowych zlokalizowanych głównie w płatach 
czołowych. Chory został zakwalifikowany do radioterapii paliatywnej na obszar OUN.

\section{Omówienie przypadku 8}

Bezobjawowe, przejściowe zaburzenia czynności wątroby, które wystąpiły u prezentowanego pacjenta po I kursie leczenia nie są częstym działaniem niepożądanym w trakcie terapii wemurafenibem (w 3. stopniu toksyczności dotyczyło 7\% chorych w badaniu BRIM-3). Leczenie zostało przerwane do momentu uzyskania poprawy do stopnia 1., a następcza redukcja dawki do 720 mg dwa razy dziennie umożliwiła kontynuację leczenia i uzyskanie stabilizacji choroby według kryteriów RECIST. Odpowiedź na leczenie utrzymywała się przez ok. 6 miesięcy. Nieznana jest przyczyna oporności na wemurafenib u prezentowanego chorego. Teoretyczną możliwość stanowi powstanie wtórnych mutacji w obrębie BRAF czy aktywacja szlaku RAS-RAF-MEK-ERK poniżej miejsca działania wemurafenibu, ale w omawianym przypadku nie przeprowadzono diagnostyki w tym kierunku.

\section{Podsumowanie}

Mutację w genie BRAF stwierdza się w przynajmniej 50\% czerniaków, z czego około 90\% dotyczy mutacji V600E [8]. Jest to dominujący mechanizm prowadzący do nadaktywności szlaku RAS-RAF-MEK-ERK w czerniakach skóry, głównie powstających w miejscach nienarażonych na długotrwałe działanie promieni słonecznych [35, 36]. Chorzy na uogólnionego czerniaka skóry z pozytywną mutacją w genie $B R A F$ charakteryzują się znamiennie młodszym wiekiem w porównaniu z grupą BRAF wild-type i wykazują gorszą tendencję czasu przeżycia całkowitego [13, 37].

Wyniki leczenia chorych na uogólnionego czerniaka są niezadowalające, jednak ostatnie lata są przełomowe w terapii uogólnionych czerniaków [1, 8, 35]. Oprócz rozwoju immunoterapii, wprowadzenie inhibitora BRAF do codziennej praktyki klinicznej pozwoliło, w porównaniu do szeroko stosowanej chemioterapii z udziałem dakarbazyny, na wydłużenie czasu do progresji i czasu przeżycia całkowitego w grupie chorych na nieresekcyjnego lub uogólnionego czerniaka [16, 28, 35].

Opublikowane w 2011 roku wyniki rejestracyjnego badania III fazy z wemurafenibem (Zelboraf) w 1. linii leczenia u wyselekcjonowanych chorych na czerniaka skóry w IV stopniu zaawansowania z mutacją BRAF V600 wykazały odpowiedzi na leczenie wynoszące $48 \%$ w grupie leczonej inhibitorem przy jednoczesnej poprawie czasu przeżycia wolnego od progresji oraz czasu przeżycia całkowitego [16]. Mediana czasu wolnego od progresji dla wemurafenibu i dakarbazyny wyniosła odpowiednio 5,3 miesiąca i 1,6 miesiąca, natomiast mediana czasu przeżycia całkowitego wyniosła odpowiednio 13,2 miesiąca i 9,6 miesiąca $[16,17]$. W 2012 roku potwierdzono skuteczność terapeutyczną innego leku z tej samej grupy (inhibitora

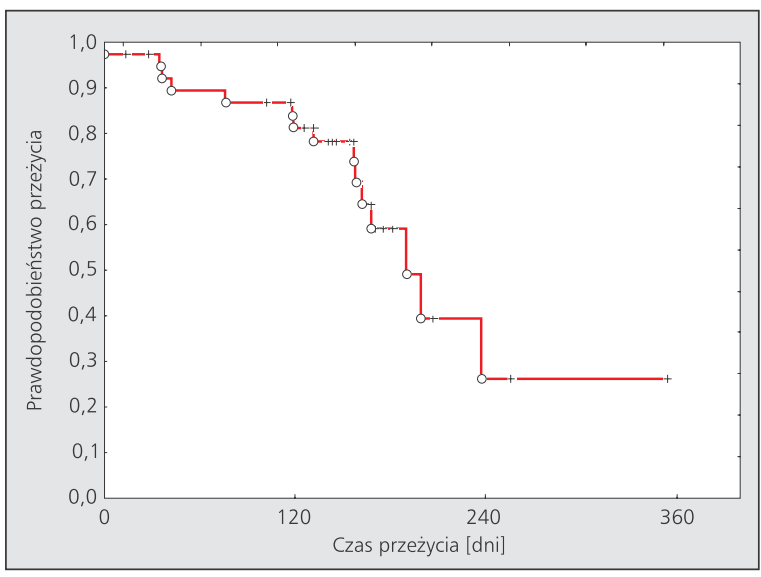

Rycina 6. Przeżycia wolne od progresji choroby w grupie 40 chorych na przerzutowe czerniaki BRAF(+) leczone wemurafenibem w Centrum Onkologii — Instytucie w Warszawie, z medianą okresu obserwacji 6 miesięcy

BRAF) — dabrafenibu (o porównywalnej do wemurafenibu skuteczności) [38].

W Polsce od czerwca 2013 roku wemurafenib jest dostępny do leczenia chorych na nieresekcyjnego lub uogólnionego czerniaka skóry z potwierdzoną mutacją $B R A F$ V600 w ramach programu lekowego [21]. Wstępne wyniki leczenia chorych na zaawansowane czerniaki w grupie 40 chorych poddanych terapii poza badaniami klinicznymi w Centrum Onkologii - Instytucie w Warszawie potwierdzają skuteczność tej metody leczenia w rutynowej praktyce klinicznej z medianą przeżycia wolnego od progresji choroby wynoszącą 6,2 miesiąca (ryc. 6). W sytuacji choroby uogólnionej wskazane jest zbadanie obecności mutacji genu BRAF na materiale utrwalonym i opcjonalnie KIT oraz NRAS [18]. Konieczna jest ścisła kontrola jakości uzyskiwanych wyników analiz molekularnych - dostępny jest zwalidowany test na obecność mutacji BRAF V600 w komórkach nowotworowych - Cobas ${ }^{\circledR} 4800$ BRAF V600 Mutation Test. Nie ma konieczności dodatkowego pobierania materiału w celu weryfikacji obecności zaburzeń molekularnych z ognisk przerzutowych, gdyż mutacja BRAF występuje wcześnie w ontogenezie czerniaka i wykazuje bardzo znaczną zgodność pomiędzy ogniskiem pierwotnym a ewentualnymi przerzutami $[18,36]$. Nie zaleca się wykonywania mutacji u chorych na pierwotne czerniaki bez przerzutów [1, 3, 18].

Istotne jest również podkreślenie, że inhibitory BRAF działają również u chorych na stabilne/bezobjawowe przerzuty do mózgu, co jak dotąd stanowiło miejsce niedostępne terapii systemowej przerzutowych czerniaków [39]. W badaniu klinicznym II fazy z wemurafenibem w grupie 142 chorych na czerniaki z obecnością mutacji BRAFV600 po wcześniejszym leczeniu miejscowym lub bez leczenia miejscowego przerzutów do ośrodkowego układu nerwowego stwierdzono odsetek obiektywnych odpowiedzi około $20 \%$, mediana PFS wyniosła około 4 miesięcy, a mediana OS 
6,5 miesiąca. Ponieważ inhibitory BRAF w wyselekcjonowanej grupie chorych na zaawansowane czerniaki (z mutacją BRAF) powodują szybką odpowiedź i kontrolę nowotworu u większości chorych, a jednocześnie czas trwania odpowiedzi jest ograniczony w związku z pojawianiem się mechanizmów oporności (mediana czasu trwania odpowiedzi wynosi 6-7 miesięcy), prawdopodobnie będą to leki z wyboru u chorych z objawami choroby o dużej masie nowotworu przed rozpoczęciem leczenia ipilimumabem, przy leczeniu którym korzyść chorzy odnoszą dopiero po 3-4 miesiącach, co ogranicza jego zastosowanie do chorych na zaawansowanego czerniaka o minimalnych objawach i powolnym przebiegu choroby $[1,3]$. Inhibitory BRAF z wemurafenibem na czele są przedmiotem intensywnych badań w terapii skojarzonej (z ipilimumabem, inhibitorami MEK, angiogenezy lub szlaku mTOR). Niezbędne są dalsze badania nad przełamywaniem mechanizmów oporności na leczenie ukierunkowane - w chwili obecnej wiemy już, że w przypadku pojawienia się oporności na inhibitory BRAF dochodzi do reaktywacji szlaku MAPK.

Poprawa wyników leczenia zaawansowanego czerniaka przy użyciu wemurafenibu jest związana z możliwością wystąpienia specyficznych działań ubocznych, wymagających doświadczenia w prowadzeniu tej terapii. Dominujące działania niepożądane obejmują toksyczność skórną (w tym nadwrażliwość na promieniowanie ultrafioletowe i wtórne nowotwory skóry - głównie raki kolczystokomórkowe o niskim stopniu złośliwości histologicznej oraz keratoacanthoma), bóle stawowe, nudności, biegunkę i zmęczenie [15]. W badaniach klinicznych II i III fazy około 40\% chorych wymagało redukcji dawki z powodu toksyczności. W zależności od nasilenia działań niepożądanych możliwa jest stopniowa redukcja dawki do $480 \mathrm{mg} 2 \times$ dziennie, doustnie. Konieczna jest właściwa pielęgnacja skóry i jej zabezpieczenie przed promieniowaniem UV. Przed rozpoczęciem leczenia inhibitorami BRAF zaleca się konsultację okulistyczną, a podczas leczenia, oprócz kontroli morfologii krwi i parametrów biochemicznych (enzymy wątrobowe, elektrolity), regularne badania dermatologiczne i monitorowanie EKG — ze względu na możliwość wydłużenia czasu QTc [40].U przedstawionych w pracy chorych odpowiednie postępowanie w przypadku pojawienia się działań niepożądanych umożliwiało kontynuowanie terapii.

Bezsprzecznie inhibitory BRAF jako względnie nowa grupa leków wymagają dalszych badań i obserwacji, niemniej stanowią ważny postęp w leczeniu chorych na nieresekcyjnego lub uogólnionego czerniaka z wykazaną mutacją w genie BRAF.

\section{Adres do korespondencji:}

\section{Prof. dr hab. n. med. Piotr Rutkowski}

Klinika Nowotworów Tkanek Miękkich, Kości i Czerniaków Centrum Onkologii — Instytut im. Marii Skłodowskiej-Curie ul. W.K. Roentgena 5, 02-781 Warszawa e-mail: rutkowskip@coi.waw.pl

\section{Piśmiennictwo}

1. Rutkowski P, Wysocki P (red.). Czerniaki skóry. W: Krzakowski M, Warzocha K (red.) Zalecenia postępowania diagnostyczno-terapeutycznego w nowotworach złośliwych 2013 rok. Tom I. Gdańsk: Via Medica; 2013, s. 419-438.

2. Miller AJ, Mihm MC Jr. Melanoma. N Engel J Med 2006; 355: 51-65.

3. Rutkowski P, Wysocki P, Nowecki Z i wsp. Czerniaki skóry — zasady postępowania diagnostyczno-terapeutycznego w 2013 roku. Onkol Prak Klin 2012; 8, 6: 219-233.

4. Charakterystyka produktu leczniczego Yervoy. Czerwiec 2012.

5. http://clinicaltrials.gov/ct2/show/NCT01844505.

6. http://clinicaltrials.gov/ct2/show/NCT01866319.

7. http://clinicaltrials.gov/ct2/show/NCT01704287.

8. Ascierto PA, Kirkwood J, Grob JJ i wsp. The role of BRAF V600 mutation in melanoma. J Transl Med 2012; 10: 85.

9. Hong DS, Vence L, Falchook G i wsp. BRAF (V600) inhibitor GSK2118436 targeted inhibition of mutant BRAF in cancer patients does not impair overall immune competency. Clin Cancer Res 2012; 18: 2326-2335.

10. Platz A, Egyhazi S, Ringborg U i wsp. Human cutaneous melanoma; a review of NRAS and BRAF mutation frequencies in relation to histogenetic subclass and body site. Mol Oncol 2008; 1: 395-405.

11. Gray-Schopfer VC, da Rocha Dias S, Maras R. The role of B-RAF in melanoma. Cancer Metastasis Rev 2005; 24: 165-183.

12. Catalogue of Somatic Mutations in Cancer (COSMIC) http://www.sanger. ac.uk/cosmic.

13. Long GV, Menzies AM, Nagrali AM i wsp. Prognostic and clinicopathologic associations of oncogenic BRAF in metastatic melanoma. J Clin Oncol 2011; 29: 1239-1246.

14. Shepherd C, Puzanov I, Sosman J. B-RAF inhibitors: an evolving role in therapy of malignant melanoma. Curr Oncol Rep 2010; 12: 146-152.

15. Charakterystyka produktu leczniczego Zelboraf. Styczeń 2013.

16. Chapman PB, Hauschild A, Robert C i wsp. Improved survival with vemurafenib in melanoma with BRAF V600E mutation. $N$ Engl $J$ Med 2011; 364: 2507-2516.

17. Chapman PB, Hauschild A, Robert C i wsp. Updated overall survival (OS) results for BRIM-3, a phase III randomized, open-label, multicenter trial comparing BRAF inhibitor vemurafenib (vem) with dacarbazine (DTIC) in previously untreated patients with BRAFV600E-mutated melanoma. J Clin Oncol 2012; 30 (supl.): abstract 8502.

18. Dummer R, Hauschild A, Guggenheim M i wsp. Cutaneous melanoma: ESMO clinical practice guidelines for diagnosis, treatment and follow-up. Ann Oncol 2012; 23 (supl. 7): vii86-vii91.

19. http://www.urpl.gov.pl.

20. www.fda.gov.

21. Program lekowy. Wemurafenib 2013

22. Manousaridis I, Mavridou S, Geordt S i wsp. Cutaneous side effects of inhibitors of the RAS/RAF/MEK/ERK signaling pathway and their management. J Eur Acad Dermatol Venereol 2013; 27: 11-18.

23. Lacouture ME, Duvic M, Hauschild A i wsp. Analysis of dermatologic events in vemurafenib - treated patients with melanoma. Oncologist 2013; 18: 314-322

24. Bradford PT, Freedman DM, Goldstein AM i wsp. Increased risk of second primary cancers after a diagnosis of melanoma. Arch Dermatol 2010; 146: $265-272$.

25. Sosman JA, Kim KB, Schuchter L i wsp. Survival in BRAF V600-mutant advanced melanoma treated with vemurafenib. NEngl J Med 2012; 366: 707-714.

26. Ribas A, Kim KB, Schuchter LM i wsp. BRIM-2: An open-label, multicenter phase II study of vemurafenib in previously treated patients with BRAF V600E mutation-positive metastatic melanoma. J Clin Oncol 2011; 29 (supl.): abstract 8509 .

27. Luke JJ, Hodi S. Vemurafenib and BRAF inhibition: A new class of treatment for metastatic melanoma. Clin Cancer Res 2012; 18: 9-14.

28. Da Rocha Dias S, Salmonson T, van Zwieten-Boot B. The European Medicines Agency review of vemurafenib (Zelboraf) for the treatment of adult patients with BRAF V600 mutation-positive unresectable or metastatic melanoma: Summary of the scientific assessment of the Committee for Medicinal Products for Human Use. Eur J Cancer 2013; 49: 1654-1661.

29. Zienciuk A, Lubiński A. Zespół wydłużonego QT — diagnostyka i leczenie. Choroby Serca i Naczyń 2006; 3: 41-46.

30. www.qtdrugs.org

31. Rochet NM, Kottschade LA, Markovic SN. Vemurafenib for melanoma metastases to the brain. N Engl J Med 2011; 365: 2439-2441.

32. Dummer R, Rinderknecht J, Goldinger SM i wsp. An open-label pilot study of vemurafenib in previously treated metastatic melanoma patients with brain metastases. J Clin Oncol 2011; 29 (supl.): abstract 8548. 
33. Dąbrowski A, Jurkowska G, Wereszczyńska-Siemiątkowska U (red.). Choroby trzustki.W: Interna Szczeklika. Podręcznik chorób wewnętrznych. Kraków: Medycyna Praktyczna; 2012, 973-996.

34. Muluneh B, Buie LW, Collichio F. Vemurafenib - associated pancreatitis: case report. Pharmacotherapy: J Hum Pharmacol Drug Ther 2013; 33: e43-e44.

35. Piotr Rutkowski (red.). Złośliwe nowotwory skóry. Gdańsk: Via Medica; 2011.

36. Colombino M, Capone M, Lissia A i wsp. BRAF/NRAS Mutation Frequencies Among Primary Tumors and Metastases in Patients With Melanoma. J Clin Oncol 2012; 30: 2522-2529.

37. Kwapisz D, Dansonka-Mieszkowska A, Koseła H i wsp. Clinicopathologic associations of BRAF mutation status in patients with metastatic melanoma. EORTCMelanoma Group Meeting. Spain. 2013; abstract P16.

38. Hauschild A, Grob JJ, Demidov LV i wsp. Dabrafenib in BRAF-mutated metastatic melanoma: a multicentre, open-label, phase 3 randomised controlled trial. Lancet 2012; 380 (9839): 358-3565.

39. Dummer R, Goldinger SM, Turtschi CP i wsp. Vemurafenib in patients with BRAF V600 mutation-positive melanoma with symptomatic brain metastases: Final results of an open-label pilot study. Eur J Cancer 2014; 50: 611-621.

40. Świtaj T, Nowecki ZI, Rutkowski P. Leczenie ukierunkowane czerniaków skóry. W: Wojtukiewicz MZ, Sierko E (red.) Leczenie ukierunkowane na cele molekularne w onkologii i hematoonkologii. Gdańsk: Via Medica; 2013, s. 420-440. 
